University of Rhode Island

DigitalCommons@URI

Open Access Master's Theses

2000

\title{
A Redevelopment Plan for Rocky Point Park in Warwick, Rhode Island
}

Robert E. Azar

University of Rhode Island

Follow this and additional works at: https://digitalcommons.uri.edu/theses

\section{Recommended Citation}

Azar, Robert E., "A Redevelopment Plan for Rocky Point Park in Warwick, Rhode Island" (2000). Open Access Master's Theses. Paper 398.

https://digitalcommons.uri.edu/theses/398

This Thesis is brought to you for free and open access by DigitalCommons@URI. It has been accepted for inclusion in Open Access Master's Theses by an authorized administrator of DigitalCommons@URI. For more information, please contact digitalcommons-group@uri.edu. 


\section{A Redevelopment Plan for Rocky Point Park in Warwick, Rhode Island}
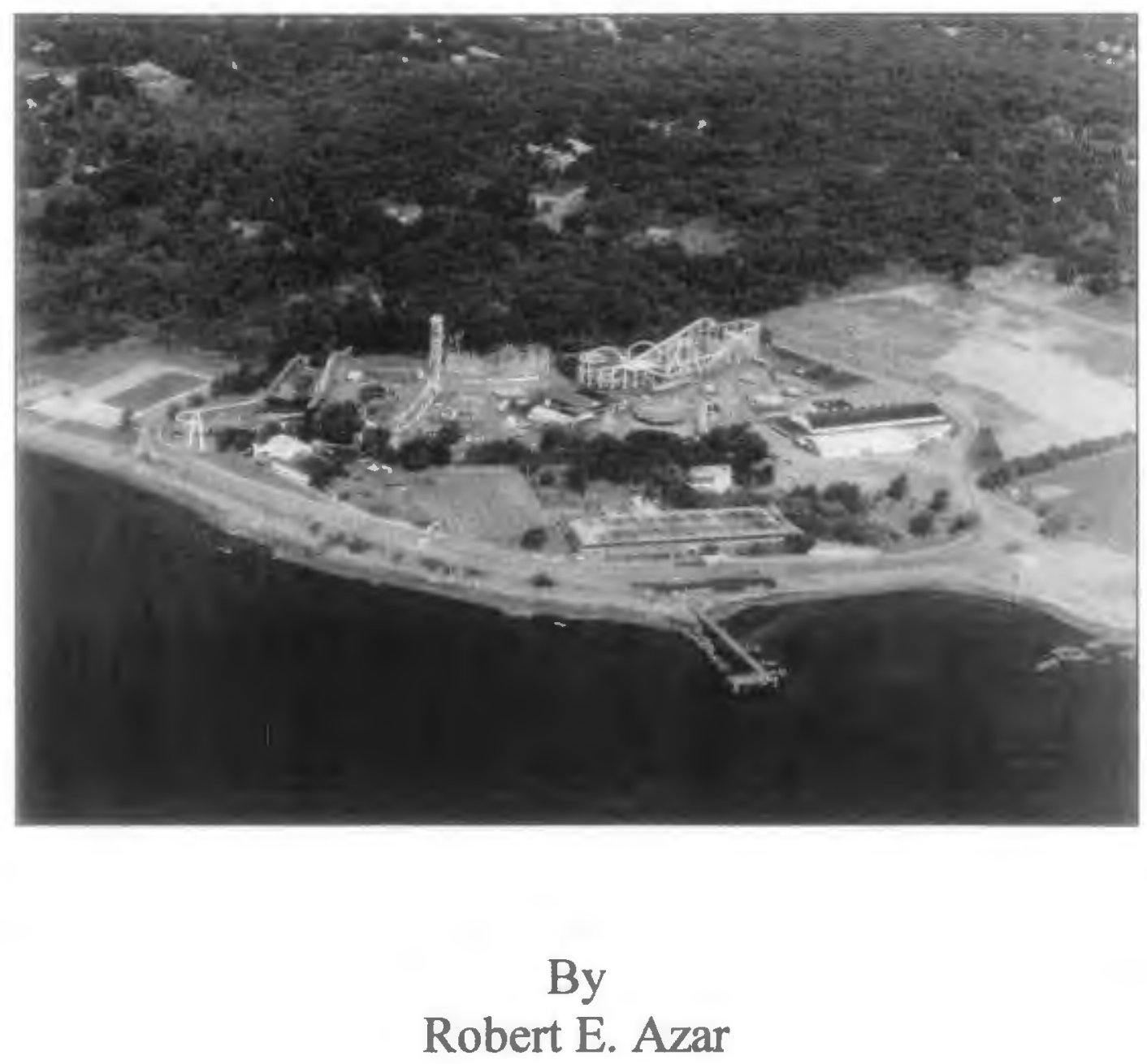

A Research Project Submitted in Partial Fulfillment of the Requirements for the Degree of Master of Community Planning

University of Rhode Island 


\section{Master of Community Planning Research Project of \\ Robert E. Azar}

Approved:

Major Professor

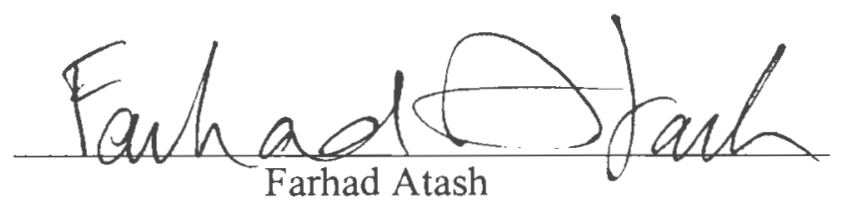

Acknowledged:

Director

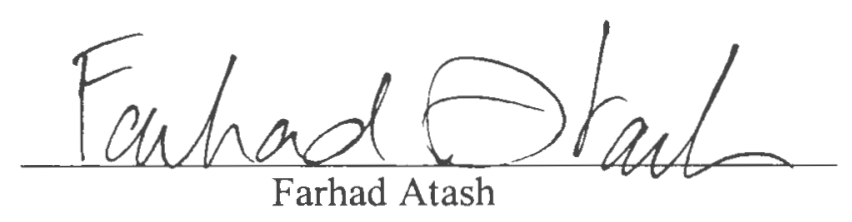




\begin{abstract}
This research project proposes a plan for the redevelopment of the former Rocky Point Amusement Park in Warwick, Rhode Island. The study first details the park's history and cultural value to the people of Rhode Island. It then defines and evaluates the environmental setting of the study area. Geographic information system (GIS) mapping is used to evaluate environmental constraints to determine the parts of the study area precluded from development and those where development is appropriate. A site survey also evaluates existing conditions of the study area. The property is next evaluated through the perspective of land use regulations and political issues.

Options for the redevelopment of the study area, including exclusively open space; low- and high-density housing; and a mix of parkland, housing and commercial uses, are explored. A concept for the redevelopment of the study area into a mixed-use village is then presented. The plan includes an open space network and areas for commercial, residential and transit uses. The development attempts to retain much of the historical character of Rocky Point while meeting modern-day needs.

The final chapter of the project discusses implementation of the redevelopment plan. It estimates the impact of this plan, both to a developer and to the city. The fiscal impact includes taxes anticipated from the new development and public services for its residents. The cost of open space acquisition is estimated and the availability of funding resources is evaluated. Finally, the city's role in implementation is considered.
\end{abstract}




\section{Acknowledgements}

Many people assisted me in the research and preparation of this study. Farhad Atash, David Westcott and William Depasquale reviewed the manuscript. Farhad encouraged me to pursue my interest in Rocky Point and was always generous with his time when I needed help. Dave has been a mentor to me for the past year. His candid assessment of my ideas motivated me to produce a better product. Bill supported my concepts and provided the invaluable perspective from the Warwick Planning Department.

Tim Delgiudice helped me gain access to the park for the site survey, recounted his unique experiences of Rocky Point and loaned me the photograph that appears on the cover. Thanks to Lidia Cruz in the Warwick Planning Department for her assistance. My parents and my sister, Bob, Judy and Beth, have also been encouraging and supportive during the past two years.

This project is dedicated to Suzanne Ambs. I couldn't have done this without her patience and love. 


\section{Table of Contents}

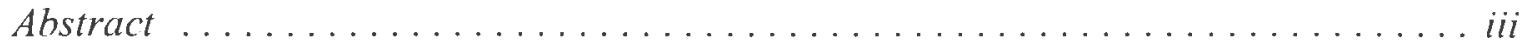

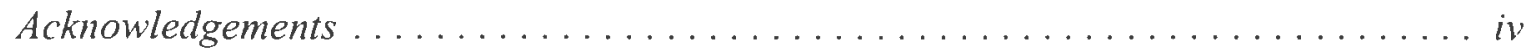

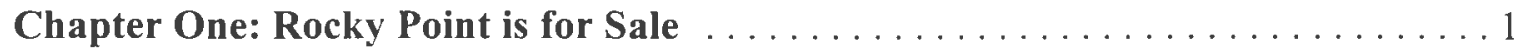

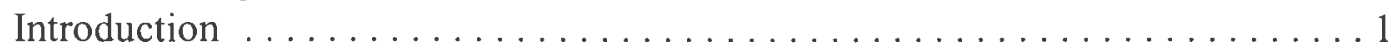

Redevelopment Proposals $\ldots \ldots \ldots \ldots \ldots \ldots \ldots \ldots \ldots \ldots \ldots$

Essential Elements of a Redevelopment Plan . . . . . . . . . . . . 3

Mixed-use Village . . . . . . . . . . . . . . . . . . . . . . . . 4

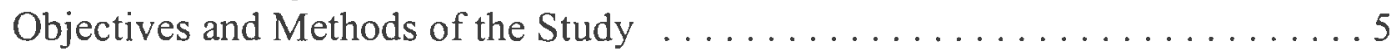

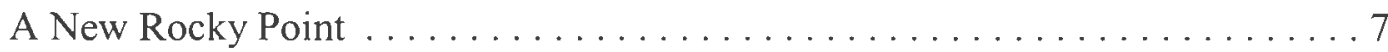

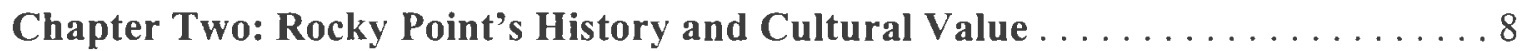

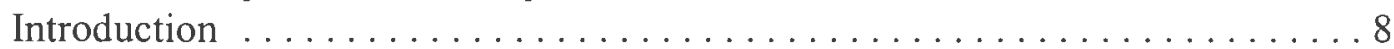

Recreational and Commercial Uses $\ldots \ldots \ldots \ldots \ldots \ldots \ldots \ldots$

Residential Uses . . . . . . . . . . . . . . . . . . . . . . . 9

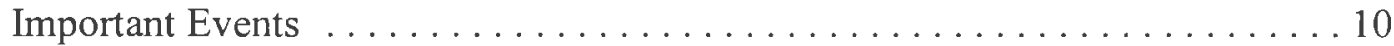

Access to Rocky Point . . . . . . . . . . . . . . . . . . . 11

Redevelopment Rumors . . . . . . . . . . . . . . . . . . . . . . 12

Bankruptcy and Closure . . . . . . . . . . . . . . . . . 12

The Future . . . . . . . . . . . . . . . . . . . . . . . 15

Chapter Three: Environmental Setting and Constraints $\ldots \ldots \ldots \ldots \ldots \ldots$

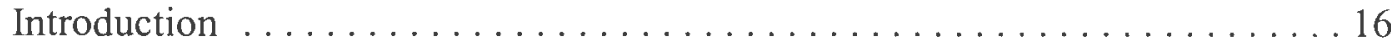

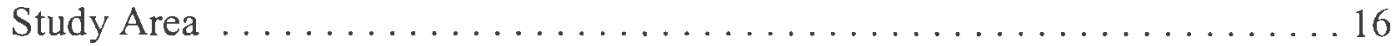

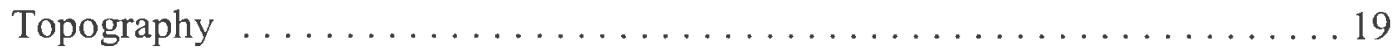

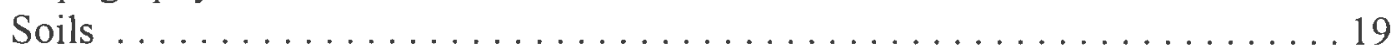

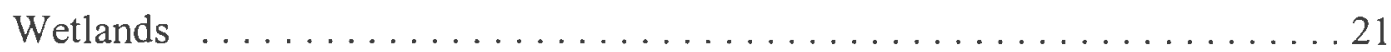

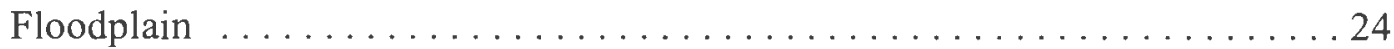

Combined Environmental Constraints . . . . . . . . . . . . . 24

Land Use and Infrastructure . . . . . . . . . . . . . . . . . 27

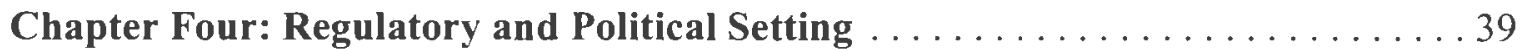

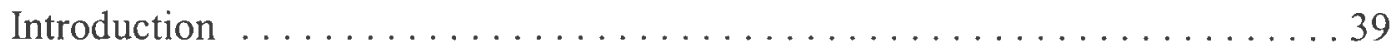

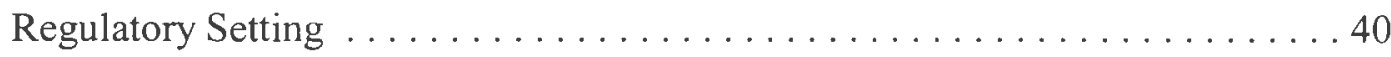

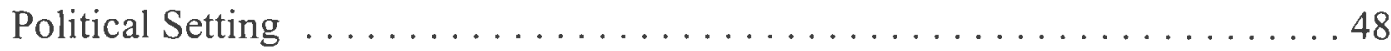

Chapter Five: Redevelopment Options $\ldots \ldots \ldots \ldots \ldots \ldots \ldots \ldots \ldots \ldots$

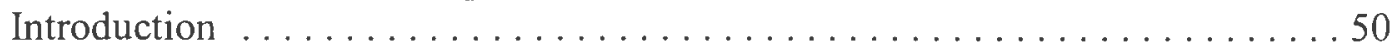

Open Space . . . . . . . . . . . . . . . . . . . . . . . . 50

Residential Development . . . . . . . . . . . . . . . . . . . 51

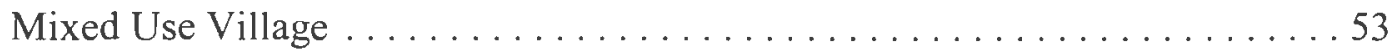

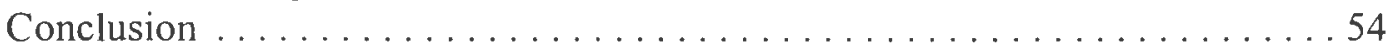


Chapter Six: A Redevelopment Plan for Rocky Point $\ldots \ldots \ldots \ldots \ldots \ldots$

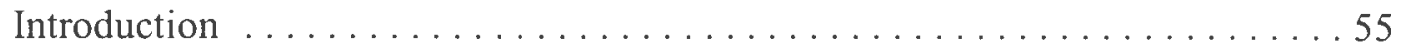

Mixed Use, PUD and the New Urbanism . . . . . . . . . . . . . 55

A Redevelopment Plan for Rocky Point . . . . . . . . . . . . . . . . . 58

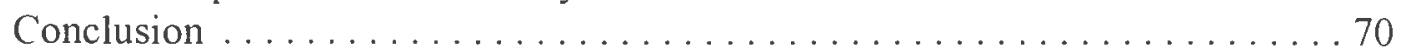

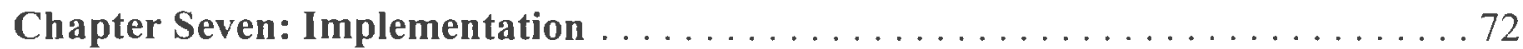

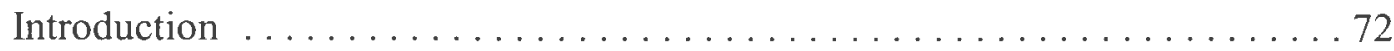

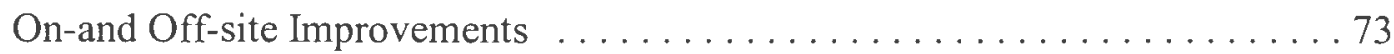

Revenues ............................. 74

Site Acquisition . . . . . . . . . . . . . . . . . . . . . . . 77

Return on Investment . . . . . . . . . . . . . . . . . . . . . . . . 79

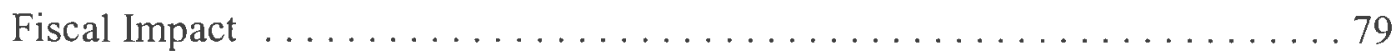

Funding Sources . . . . . . . . . . . . . . . . . . 81

Warwick's Role in Implementation . . . . . . . . . . . . . . 82

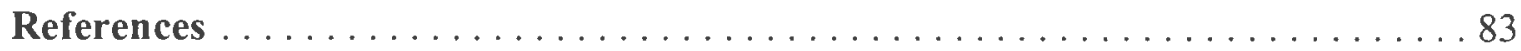




\section{List of Tables}

No. Title

1 Site improvement costs

2 Tax revenues

\section{List of Figures}

No. Title

$1 \quad$ Rocky Point study area . . . . . . . . . . . . . . . . . 17

2 Plat and lot map for Rocky Point study area $\ldots \ldots \ldots \ldots \ldots \ldots \ldots$

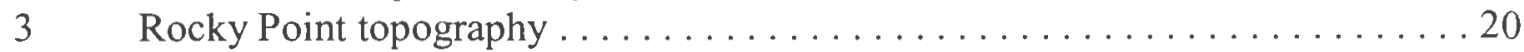

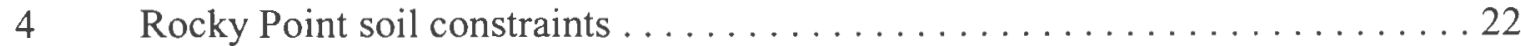

$5 \quad$ Rocky Point wetlands . . . . . . . . . . . . . . . . . . . . 23

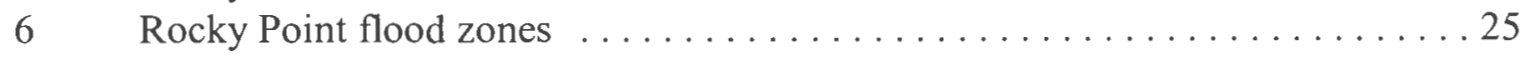

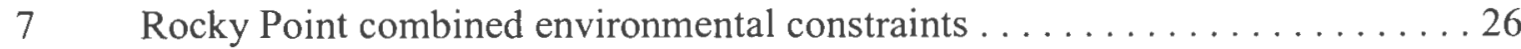

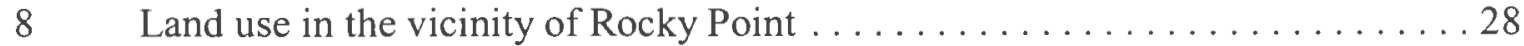

9 Areas of developed and undeveloped land . . . . . . . . . . . . . . . 29

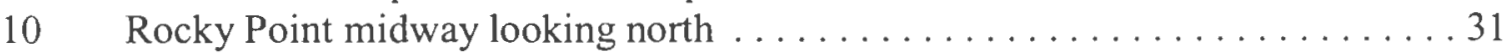

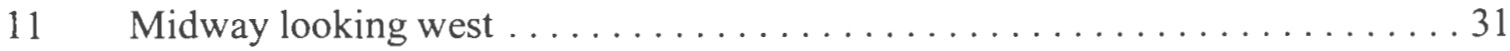

12 Abandoned amusements and concession stands $\ldots \ldots \ldots \ldots \ldots \ldots \ldots \ldots$

13 Carousel structure with Palladium in back to the right $\ldots \ldots \ldots \ldots \ldots \ldots 32$

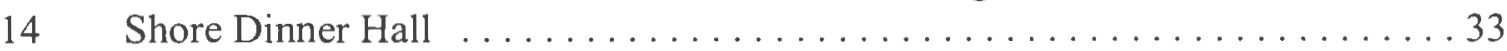

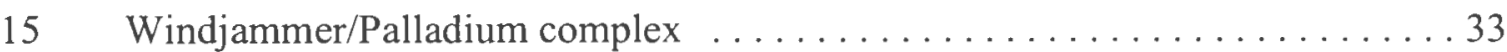

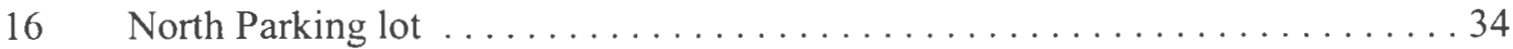

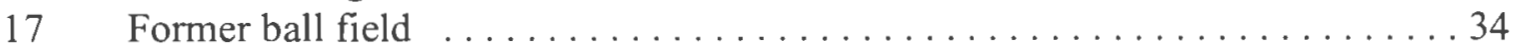

18 Rocky Point's pier . . . . . . . . . . . . . . . . . . . . 36

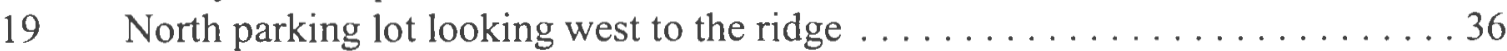

20 Sandy beach looking south to Rocky Point $\ldots \ldots \ldots \ldots \ldots \ldots \ldots \ldots$

21 Abandoned house ................................ 37

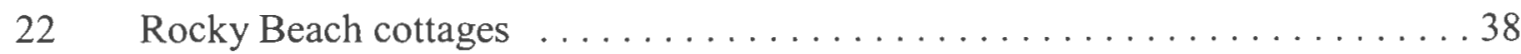

23 Sandy beach looking north to Rocky Beach cottages $\ldots \ldots \ldots \ldots \ldots \ldots$

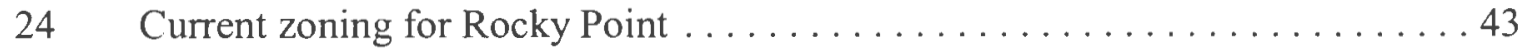

25 Houses in Wickford Point . . . . . . . . . . . . . . . . 57

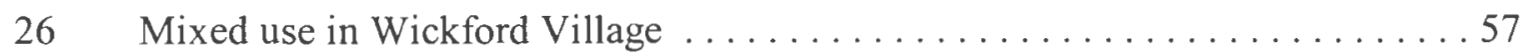

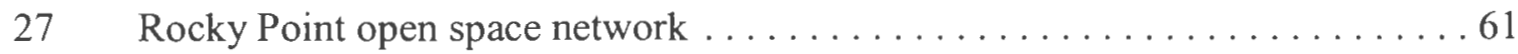

$28 \quad$ Rocky Point Village concept plan ..................... 62

29 Rendering of proposed improvements to Shore Dinner Hall . . . . . . . . . . . 65 


\section{Chapter One}

\section{Rocky Point is For Sale}

\section{Introduction}

The property formerly known as Rocky Point Park is for sale for $\$ 10$ million (DePaul, 1999). Since the 160 year-old amusement park was closed in 1996, developers have been eyeing the 125 acres of land for redevelopment. The potential is enormousthis is one of the largest vacant pieces of coastal land in Rhode Island. It affords magnificent water views. There are two sandy beaches and a pier on the property. But due to a number of environmental, economic and political reasons, the land has remained vacant for years.

This is a critical time for this important piece of property. It is too valuable to remain vacant for long. While it does, there exists a window of opportunity to carefully plan for its future. This research project proposes a redevelopment plan for Rocky Point that incorporates planning and design principles that are appropriate for the unique characteristics of the site. The plan also respects the history of the property by keeping much of it as a public space, incorporating commercial and residential uses and providing public access to the waterfront.

\section{Redevelopment Proposals}

Several proposals for redevelopment of the former Rocky Point property have been made public to date (Wyatt, 1995, 1996; Howell, 1997). They typically involve constructing hundreds of condominium units, duplexes and single-family homes. Some 
proposals call for selling some of the property that is unsuitable for development to the City of Warwick or to the state. So far none of the proposals have been anything more than concepts. Why is this the case?

As with any coastal site in Rhode Island, there are considerable environmental constraints to development. Wetlands, coastal features and unsuitable soils are strictly regulated. Their existence limits development and reduces the area suitable for building considerably. Perhaps more importantly, there are economic and political constraints to rebuilding Rocky Point. Years of fractious disputes between owners and creditors have resulted in increasing costs that must be recouped. Developers believe that in order for them to maximize their investment, the current zoning (single family, with lots ranging in size from 10,000 to 40,000 square feet) would have to be changed to allow for highdensity residential development. This is evidenced by the fact that no plans for development have been proposed that have conformed to the existing zoning requirements.

A change in zoning is not easy to acquire- there are several layers of city government that would review and approve any application. Further, any redevelopment of this landmark property would be difficult without public acceptance, and the public is unlikely to accept haphazard development on a site that for many has sentimental value (Wyatt, 1999). So far, the planners and politicians in Warwick have not reacted favorably to the conceptual development proposals for Rocky Point. What is needed is a plan that will balance the needs of the city, the owners and the public. 


\section{Essential Elements of a Redevelopment Plan}

In order for a redevelopment plan of Rocky Point to achieve this balance, it must contain the following elements: public open space, at least along the entire coastline of the property; a mix of residential and commercial (retail) space; access to the commercial facilities and the open space by the general public; reuse of existing buildings, rehabilitation of the pier for public use; and design features that will make for a more livable community.

Access and Open Space

Rocky Point has been accessible to the general public since the 1840 s. Generations of Rhode Islanders have visited the park, not just for its amusements, but also to use its beaches, to fish from the pier or to get a glimpse of the wildlife, including seals and shorebirds that frequent the waters off the point. Because of its heritage, its outstanding value as a multi-use park, and its location in the sensitive coastal zone, Rocky Point should be developed in a way that maximizes public access and open space.

\section{Commercial and Residential Uses}

Rocky Point has a rich history of commercial uses. First as a location of steamship liner-sponsored picnics, later as an amusement park with a restaurant, ballroom, function hall, and the "world's largest shore dinner hall," entrepreneurs have taken advantage of the coastal location to lure customers from all over southern New England. In keeping with this heritage, Rocky Point should be developed as a mixed-use 
village, with commercial uses incorporated into a residential development and servicing residents of the village as well as visitors to the park.

The Pier

The pier at Rocky Point was an important part of its success. For years it was the only access to the property. More recently it provided a berth for pleasure boaters who frequented the Shore Dinner Hall's take-out window, and for the Bay Queen, a commercial cruise ship. The pier should retain these multiple uses and should also serve a new purpose as a transit node for Narragansett Bay ferry service.

\section{Planning and Design Principles}

Through proper site planning and design, a mixed-use development can be a better place to live and visit. A development at Rocky Point village should incorporate site planning and design principles so that it will fit harmoniously with the natural features of the site and encourage activities that promote a sense of community.

\section{Mixed-use Village}

With these essential elements in mind, the best use for this property, therefore, is actually a mix of uses. Rocky Point should be redeveloped as a village, with homes, shops and parkland. This mixed-use community will be a wonderful place to live, with beautiful views and easy access to natural beauty and commercial amenities. As it was

for 160 years, it will be a great place to visit, by land or by sea, to shop or to recreate. 
With the rehabilitation of the pier, it will also be a transit node that serves commuters to Providence, Newport and elsewhere.

Warwick's Comprehensive Plan states, "a reuse of (Rocky Point) could utilize planned unit development, cluster development, and other techniques to best suit the large size and natural features of this site.” (Warwick, 1995). This research project proposes to follow this advice. Envisioned is a planned unit development for Rocky Point that incorporates New Urbanist planning and design principles, areas of commercial development, cluster-style housing to maximize open space, and sensitivity to the outstanding environmental features of the land.

\section{Objectives and Methods of the Study}

This research project proposes a plan for the redevelopment of Rocky Point. The following six sections will lay the groundwork and then describe the plan in detail as follows:

Rocky Point's History and Cultural Value

The study first discusses why this place is worthy of such a meticulous inquiry by detailing the park's history and cultural value to the people of Rhode Island.

\section{Environmental Setting and Constraints}

In order to determine Rocky Point's development potential the study defines and then evaluates the environmental setting of the study area. Geographic information system (GIS) mapping is used to evaluate environmental constraints to determine the 
parts of the study area precluded from development and those where development is appropriate. A site survey also evaluates existing conditions of the study area.

\section{Regulatory and Political Setting}

The study area is evaluated through the perspective of Federal, State and local land use regulations. The political issues involved with redevelopment of this site are also considered.

\section{Redevelopment Options}

Options for the redevelopment of the study area are explored with respect to the essential elements noted above. The options include exclusively open space, low- and high-density housing and a mix of housing, commercial (mainly retail) uses and open space.

\section{A Redevelopment Plan for Rocky Point}

A concept for the redevelopment of the study area into a mixed-use village is

presented. The development is in accordance with the Warwick planned unit development overlay district and incorporates New Urbanist planning and design principles in laying out the mix of land use. The plan includes an open space network for active and passive recreation, and areas for commercial, residential and transit uses. The development attempts to retain much of the historical character of Rocky Point while meeting the modern-day needs. 


\section{Implementation}

The final chapter of the project discusses implementation of the redevelopment plan. It estimates the impact of this plan, both to a developer and to the city. Development costs include those for land acquisition and land improvement. The fiscal impact includes taxes anticipated from the new development and public services for its residents. Where open space acquisition is proposed, the cost is estimated based on recent appraisals and on anticipated exactions from the developers. The availability of funding resources will also be evaluated. Finally, the city's role in implementation is considered.

\section{A New Rocky Point}

Someday soon, this scenic piece of property will be transformed. The land will be cleared and most likely, new buildings will be erected. The people of Warwick and of Rhode Island have a choice: they can allow the land to be developed in a haphazard way, perhaps as a high-density condominium complex with no public access, or they can insist on something better. It is hoped that this plan might serve as a blueprint for a commitment to a higher level of land use planning, especially for a place that means so much to so many. 


\section{Chapter Two}

\section{Rocky Point's History and Cultural Value}

\section{Introduction}

Rocky Point has a long history as an attraction for Rhode Islanders. For nearly 160 years, it was a functional mixed-use development. Today, it is vacant and for sale. There are no rides on the midway, the Shore Dinner Hall is padlocked shut, and the pier is broken in half, having been ravaged by years of storms. Rocky Point will be redeveloped eventually. Hopefully its redevelopment will respect the park's long and varied history as a Rhode Island landmark. This chapter will recount this history and evaluate Rocky Point's value to the people of Rhode Island.

\section{Recreational and Commercial Uses}

First as a nice place to picnic for daytrippers, and later as a full-blown amusement park, Rocky Point has served as an attraction for recreational and commercial uses. With Rocky Point, it is difficult to clearly distinguish recreation from commerce; for the most part, recreation was a business for the owners of the park.

Rocky Point's history as a public attraction dates to the 1840s, when Captain William Winslow brought Sunday school classes from Providence to the property for weekend outings. Winslow eventually bought 89 acres of land around the Point in 1847 and made a business out of transporting people in his steamboat to "Winslow's Rocky Point" for shore dinners. With the addition of swings and a carousel, Winslow had the beginnings of an amusement park (Wyatt, 1999). 
In the second half of the $19^{\text {th }}$ century, shore attractions were hugely popular with Rhode Islanders. By 1852, Rocky Point had become the location of a competing resort, J.A. Littlefield's Horn Spring. Oakland Beach on Greenwich Bay and Crescent Park in East Providence were also competing with Rocky Point (Wyatt, 1999). To keep up with the other resorts, Rocky Point kept developing. It added a hotel, a vaudeville theater and an observation tower in the 1860 s. Major league baseball was played at the point in the early 1900 s, drawing crowds of up to 20,000 . Food was always a major attraction of the park. Its shore dinners featured seafood from the bay and fruits and vegetables grown on the park grounds (Wyatt, 1999).

Hit hard by the hurricanes of 1938 and 1954, Rocky Point was rebuilt both times (D'Amato, 1992). The park also weathered economic storms, riding out the Great Depression and many periods when attendance lagged (Wyatt, 1999). All the while, it kept growing and adapting to the fickle desires of the public. In recent years, commercial operations on the property included the amusement park, the zoo, the saltwater pool, the batting cage, the Cliff House Lounge, the Windjammer and Palladium function halls and the 4,000-seat Shore Dinner Hall. It should be noted that not all recreation was of a commercial nature; there was also free recreation. Many people took advantage of the sandy beaches for swimming and the rocky areas and the pier for fishing.

\section{Residential Uses}

Besides its commercial and recreational uses, Rocky Point has had a history of residential uses. Along with the hotel, in the 1860 s owner Byron Sprague constructed a summer residence. Rock Cottage, which still stands on a ridge above the Shore Dinner 
Hall, was also built in the 19 th century, and was used as a residence for park employees.

In 1984, owners of the park bought 29 acres of land to the north known as the Rocky Beach community. On this land, 73 lots are leased to people who own cottages there. Most of these houses are used as summer residences, but some are used year-round (Wyatt, 1999).

\section{Important Events}

Rocky Point has been the site of many events that are important contributors to Rhode Island History. Below is a sample.

- Rocky Point was the site of gatherings of Rhode Island Civil War Veterans for decades after the War (D'Amato, 1992).

- In 1877 , President Rutherford B. Hayes visited the park. He made the first presidential telephone call, to Alexander Graham Bell in Providence (D'Amato, 1992).

- Al Jolson and Providence's George M. Cohan performed at Rocky Point's vaudeville theater in the mid-1800s (Wyatt, 1999).

- Stephen A. Douglas, campaigning against Abraham Lincoln in 1860, gave a speech at the park to an audience of thousands (Wyatt, 1999).

- George Bush was the second President to visit the park in 1989 for a campaign fundraiser at the Palladium (Wyatt, 1999). 


\section{Access to Rocky Point}

Since its first use as a public attraction, Rocky Point was accessed by water. In fact, for decades this was the only way to reach the point. In the late 1860 s, the American Steamship Company acquired the park. It ran ships to the park six times hourly. Rocky Point's popularity resulted in competing steamship lines also trying to gain access to the pier. In a move to protect its investment, the American Steamship Company installed a device at the pier that deployed wooden spikes whenever a competing ship would attempt to dock (Wyatt, 1999).

The days of the steamship wars are long gone but until its closure, Rocky Point's

pier was still popular. Scores of pleasure boaters would dock up to purchase chowder and clamcakes at the Shore Dinner Hall's take-out window. Also, Rocky Point was a port of call for commercial cruise ships such as the Bay Queen.

Rocky Point was also served by rail. Trolley cars served the park until they were replaced by "trackless trolleys" in 1948 (Wyatt, 1999). More recently the primary access to the park has been by automobile. This created headaches for local residents, as the local streets in Warwick Neck were never designed to handle the traffic volume that the park attracted. On some busy summer days, cars could be backed up to West Shore Road, making it difficult for locals to get to or from their houses. Parking for all these personal vehicles and tour buses was accommodated in dozens of acres of lots surrounding the midway. 


\section{Redevelopment Rumors}

Before Rocky Point closed for good in 1996, there were at least two times in this century when it was considered for redevelopment. Both of these came when business was lagging: in 1909 there were suggestions that the state should acquire it for a public park (Wyatt, 1999). In the 1940s, "tentative overtures were made to build residences on the property, ... but soil tests showed it would be extremely difficult, if not impossible, to develop most of the land" (Wyatt, 1999: 17).

\section{Bankruptcy and Closure}

The changing taste of the public and the Rhode Island credit union crisis were two factors in the ultimate demise of Rocky Point Park. In 1990, the Federal Deposit Insurance Corporation (FDIC) seized the Bank of New England and called in a $\$ 500,000$ loan on the property (Wyatt, 1995b). Rocky Point apparently needed even more than $\$ 500,000$. To meet its expenses and avoid bank foreclosure and auction, it borrowed $\$ 5.5$ million at an annual interest rate of $15.5 \%$ from Fairway Capital, a consortium of lenders that included Arnold Kilberg of Providence (Wyatt, 1995b).

The loan did not end Rocky Point's money problems. Within a few years the park was in trouble again. To avoid a foreclosure on a tax lien by the City of Warwick, the three corporations that made up Rocky Point (Captain Rocky, Inc., Rocky Point Amusement Park, Inc. and Kiddy Land, Inc.) filed for Chapter 11 bankruptcy in November of 1994 . They claimed $\$ 9$ million in debts from 145 creditors (Wyatt,1995a). Nevertheless, the park was open for business for the 1995 summer season. 
In October of 1995, a reorganization plan was approved by a federal judge who authorized a restructuring of the debt and the creation of a limited liability corporation to take the place of the three bankrupt corporations. The plan allowed the new corporation to either operate the park or liquidate it and create a residential development on the land (DePaul, 1996). The owners chose the second option. On January 12, 1996, C.R. Amusements, LLC was created. Concurrently, Moneta Capital, the owner of a 51 percent share of the park, announced that the park's assets would be liquidated (Wyatt, 1996a).

The closure prompted anxiety in many in Warwick: neighbors feared a highdensity condominium development in their back yards, the city expressed concern over access to the shoreline and the impact of a new development on schools, and Rocky Beach Residents wondered what would become of their valuable land (DePaul, 1996).

Newspapers reported that Moneta Capital was planning a 447- unit development of houses and condominiums at Rocky Point. An analysis by the City of Warwick, however, determined that the current zoning of the Rocky Point land allowed for roughly 160 houses and no condominiums. The City adopted a posture that it was willing to negotiate for public ownership of the shoreline in exchange for the higher density that the owners wanted (DePaul, 1996).

The 447-unit development never came to fruition. Since its introduction, several alternative plans have been floated. To minimize the effect on schools, a retirement community was suggested (Wyatt, 1996b). Councilman Carlo Pisaturo, whose Ward 5 includes Rocky Point, has also weighed in. Calling Rocky Point "a significant piece of America," (Broberg, 1996) he suggested a municipal golf course (Wyatt, 1996c). He also proposed a public bailout of the park to keep it alive. He said, "if I can keep this park 
going for one season and get Michael Jackson to see it, I bet he'd write a check" (Polichetti, 1996).

Michael Jackson never saw the park. And Pisaturo's plan to bail it out was rejected. Other maneuverings to force the park to stay open also failed, and the owners went ahead with their own plan, to auction off the assets of the park (Liberman, 1996). Meanwhile, the City conducted a preliminary environmental assessment of the property and revealed that only 50 to 53 acres of the 125 -acre property could be developed due to environmental constraints (Warwick, 1996). The City also had an appraisal of the property performed (Cooke, 1996a, 1996b) The appraisal put a value of between $\$ 951,000$ and $\$ 1,037,000$ on the developable land (not including Rocky Beach) and $\$ 1.3$ to $\$ 1.4$ million on the undevelopaple shoreline (which was proposed for conservation land).

The auction of the assets went ahead on April 16 and 17, 1996, but there was a new twist in this already twisted tale. On the second day of the auction, officials of $\mathrm{C}$. R. Amusements announced that there would be a "Rocky Point Family Fair" that summer, featuring new rides that would be brought in and run by an outside vendor (Wyatt, 1996d). Rocky Point was not dead yet. However, the Family Fair lasted just two seasons. By the end of the summer of 1996, redevelopment plans were again surfacing. The most detailed proposal made public to date was introduced in May of 1997. It called for 232 condominium housing units. It also proposed to sell the Rocky Beach property to its tenants association and 54.8 acres of the property to the City for $\$ 1.5$ million. The plan called for the access road to the park to be a private road for residents. Public access to 
the City-owned property would be via Rocky Beach Avenue (Howell, 1997). Again, this plan never made it beyond the concept phase.

In 1998, Kilberg filed for Chapter 7 liquidation of Rocky Point. A U.S. Bankruptcy Court judge subsequently ordered the property to be sold (DePaul, 1999). As of this writing, Rocky Point is for sale for $\$ 10$ million. Developers continue to eye the property, but its high price and significant constraints to development have so far prevented its purchase.

Kilberg ultimately may have no say over the sale of the land. In late March, 2000, a federal judge ordered the U.S. Small Business Administration to become the receiver of Fairway Capital Corp. and Moneta Capital Corp. and has barred Kilberg from liquidating any of the companies' assets (Malinowski and Stanton, 2000). Moneta and Fairway were licensed by the government as Small Business Investment Companies (SBICs), with the authority to distribute loans from the SBA. The judge found that the companies had misused the money, paying some personal debts and engaged in prohibited real estate deals.

\section{The Future}

Rocky Point has had a colorful past. Any person who has lived in Rhode Island for more than a few years has a memory of the park. This past is important and should not be forgotten when the park is redeveloped. It is hoped that Rocky Point might be redeveloped in a way that respects its history. When, in the future, people visit the land they should not bemoan the fact that what they once loved is gone. They should rejoice that at least part of what was so special has been preserved. 


\section{Chapter Three}

\section{Environmental Setting and Constraints}

\section{Introduction}

Rocky Point is not just a former amusement park. It is also a geographic feature. One lot in the City of Warwick contains both of these entities. But this lot is one of 14 contiguous and nearby lots owned by the same party. This chapter will define a study area and thereby clarify what is meant by the term "Rocky Point." It will also assess the study area's important environmental features and constraints to development.

\section{Study Area}

The study area is located in eastern Warwick, Rhode Island, in the northern part of Warwick Neck (Figure 1). It encompasses shoreline of Narragansett Bay on its eastern and southern sides. The study area is approximately 15 miles by road to Providence and 6.5 miles to T.F. Green Airport. The intersection of the nearest commercial-strip collector roads, West Shore Road (Route 117) and Warwick Avenue, is 1.5 miles from the entrance to Rocky Point's access road.

The party known as "Saul and Co. (Ajax Financial)," formerly known as C.R. Amusements, LLC, owns the land formerly occupied by Rocky Point Amusement Park. It is listed in the City of Warwick's tax assessor's records as Plat 380, Lot 1. This party also owns 13 other lots in the vicinity of this lot: in Plat 380 , Lots 3 and 281; in Plat 381, Lots 38, 39, 40 and 41; and in Plat 379, Lots 8, 9, 158, 159, 425, 426 and 445 (Figure 2). All of this property, a total of 124.57 acres, is for sale for $\$ 10$ million. Plat 379 , Lots 9 and 159 contain single-family houses; the house in Lot 9 is vacant, the one in Lot 159 is 


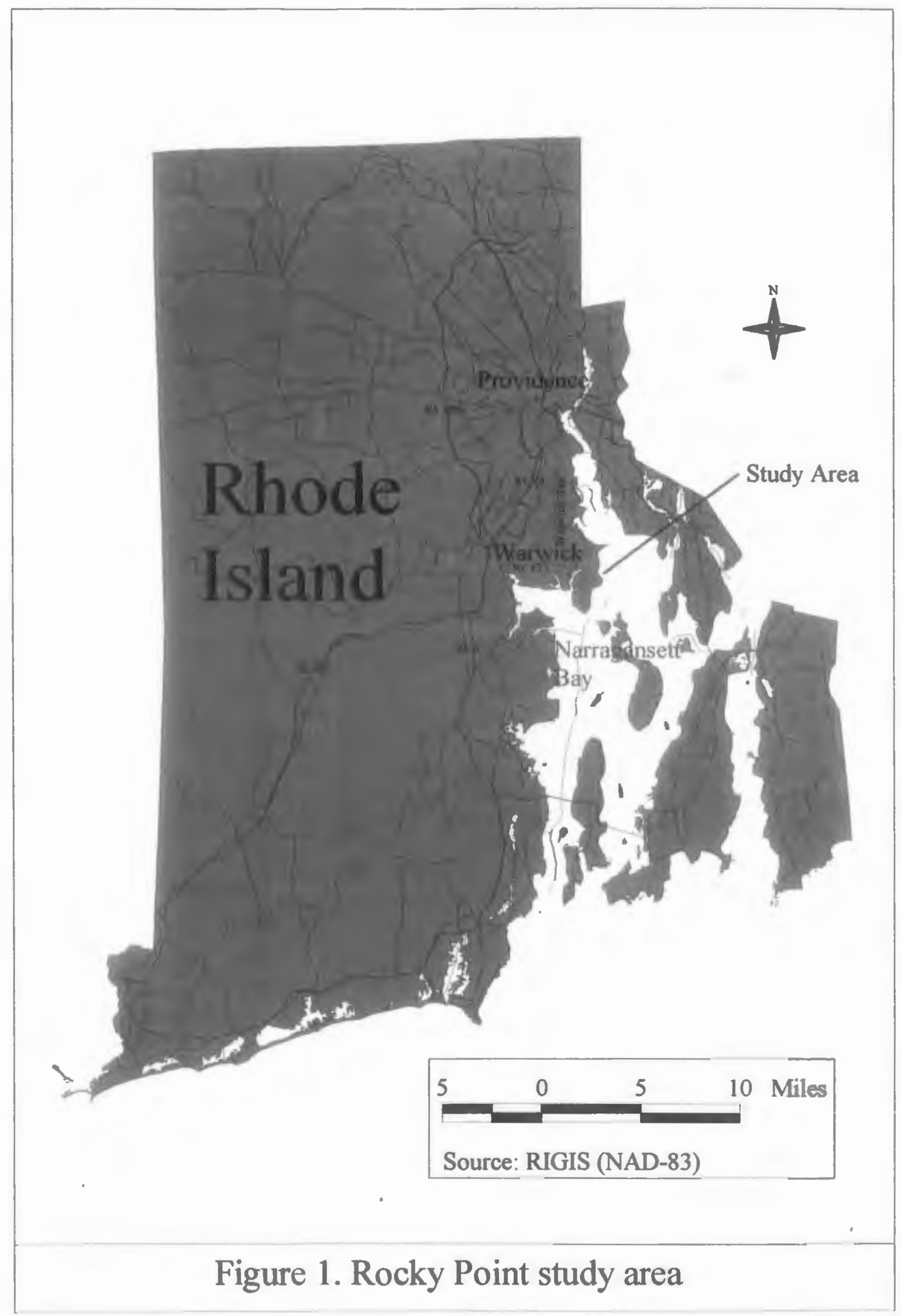




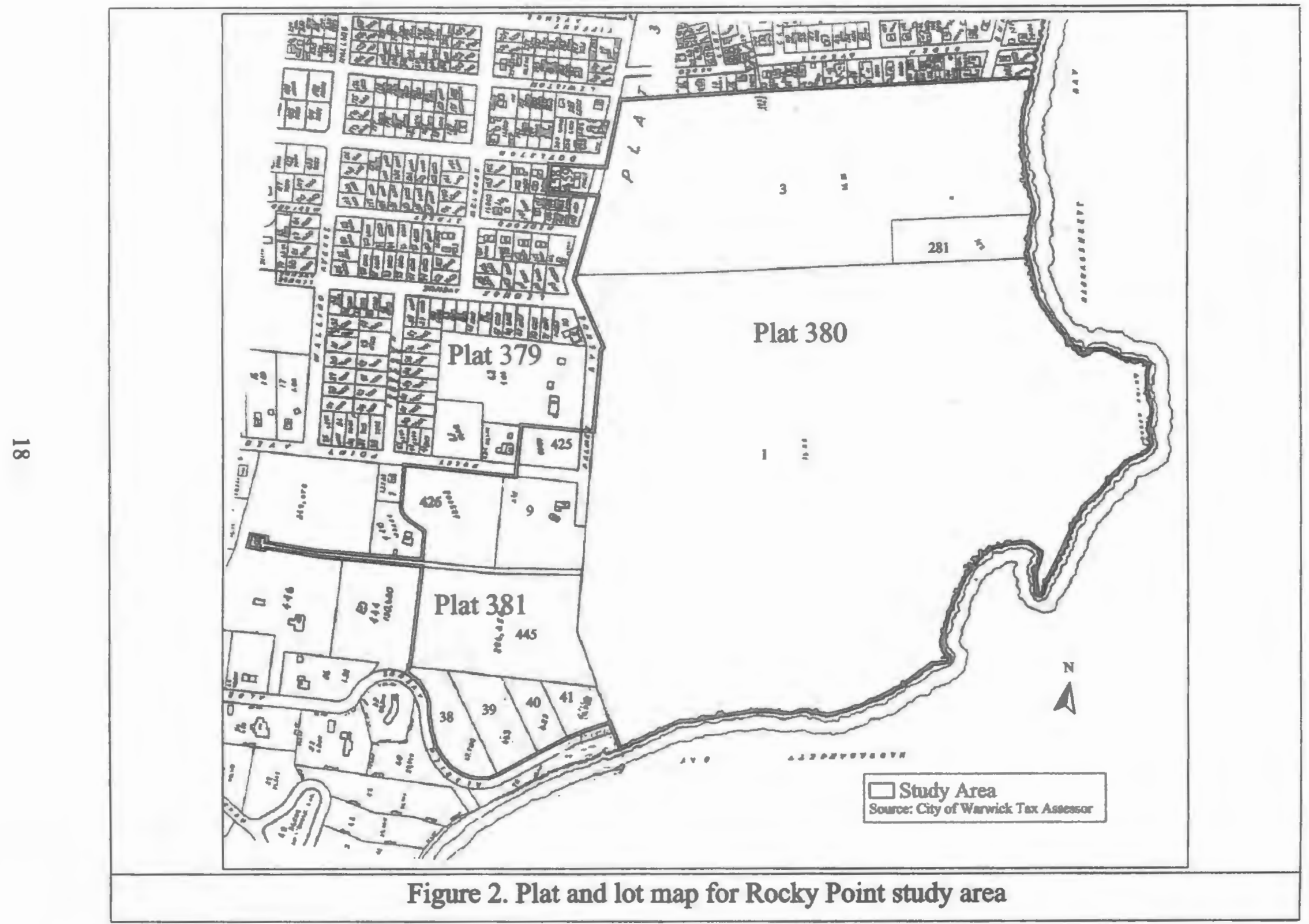


occupied. Lots 8 and 445 in Plat 379 are landlocked. The four lots in Plat 381 are theoretically accessible by Aldrich Avenue, but the road appears to end short of what is shown on the plat map, leaving up to three of these lots inaccessible by road. The Rocky Beach Community is in Plat 380, Lots 3 and 281 in the northern portion of the study area.

\section{Topography}

The study area consists of a wide variety of lowland and upland occupied by wetland, forest, field, coastal features and manmade features (Figure 3). A ridge, up to 100-feet above sea level, divides the western third of the land from the eastern portion. West of the ridge is a depression that contains wetlands that drain to the south and into the Bay. East of the ridge, the land slopes gradually down to the shore. The geographical feature of Rocky Point protrudes into upper Narragansett Bay from the bay's western shore. It features a rocky shore and rock outcroppings. North of the Point is a sandy beach that gives way to rocky beaches further up the shore. South of the point is a ten- to twenty-foot high manmade shoreline formed of fill and riprap. In the southwestern portion of the shore is another sandy beach.

\section{Soils}

The study area contains many different types of soils, according to the Rhode Island Soil Survey (1981). Rocky Beach and much of the midway area are built on urban soil complexes that are moderately to well drained. The center of the midway sits on Canton and Charlton fine sandy loams that are characterized by sloping land, boulders and rock outcrops. The north-south ridge is constituted of rock outcrop-Canton complex 


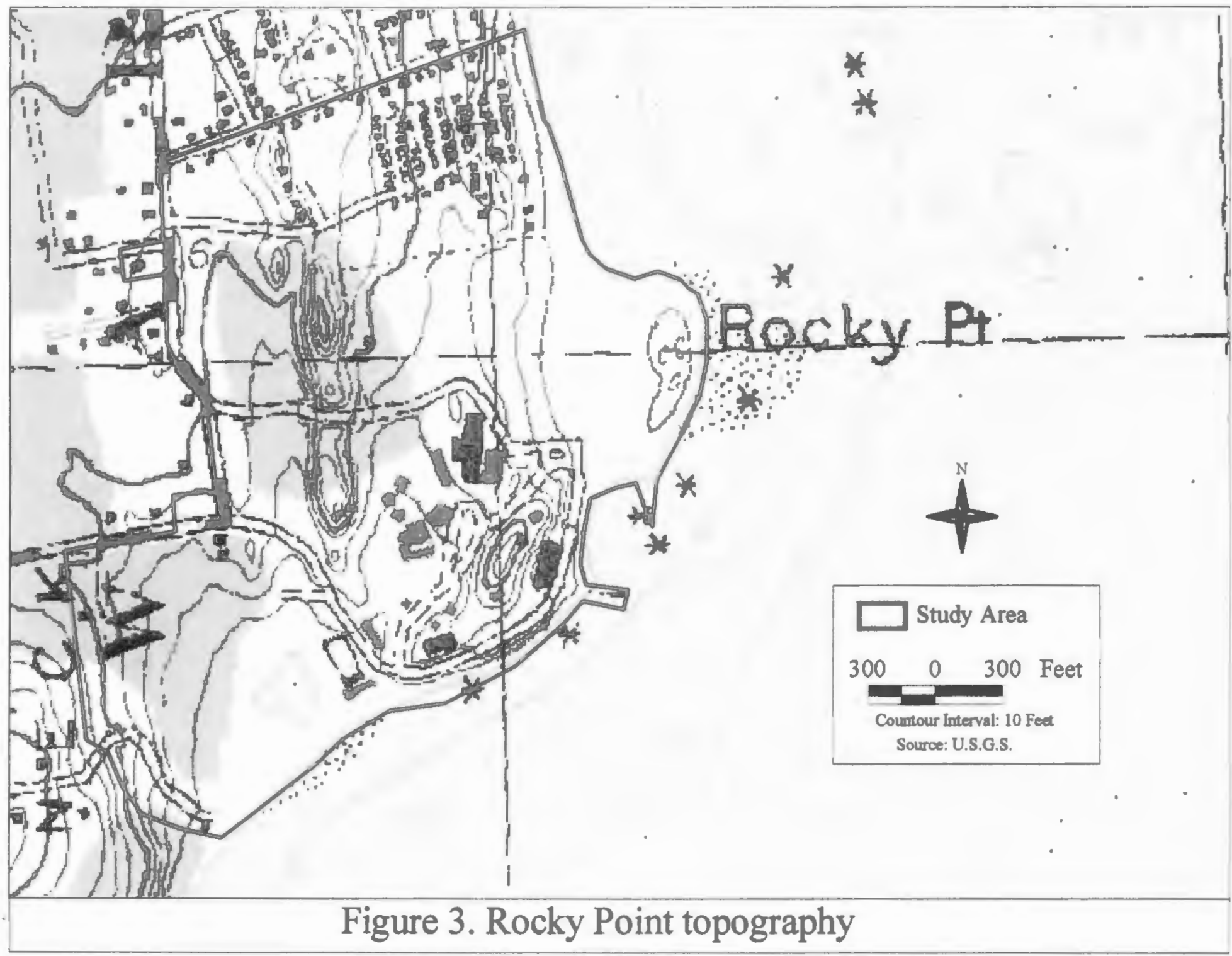


soils, described as bare, hard rock and well-drained soils on glacial upland hills and ridges. West of the ridge, corresponding with the wetland areas, is Stissing silt loam, a poorly drained soil.

RIGIS lists four types of constraints to development due to the above-listed soils in the study area (Figure 4). The north-south ridge and areas of shoreline are described as having severe constraints due to rocky or sandy conditions. West of the ridge, generally corresponding with wetland areas, and in the eastern, lowland portion of the site are areas of hydric soils. These soils have a water table at or within 18 inches of the surface. Other areas of the site have seasonal high water (19 to 42 inches below the surface) or constraints due to bedrock or steep slopes. Land with severe soil constraints or hydric soils, calculated using AutoCAD, accounts for approximately $2,453,867$ square feet, or 56 acres of the study area.

\section{Wetlands}

Wetlands in the study area are found primarily in its western portion (Figure 5). According to RIGIS, in this area they consist of deciduous forested wetland interspersed with areas of shrub swamp, marsh and two small areas of open water. These wetlands are the southern terminus of a larger wetlands system that drains from north to south into the Bay. In the eastern portion of the site, only areas of the shoreline are classified as wetlands by RIGIS. The area of wetlands within the study area, calculated by using AutoCAD, totals roughly 841,605 square feet, or 19 acres. 


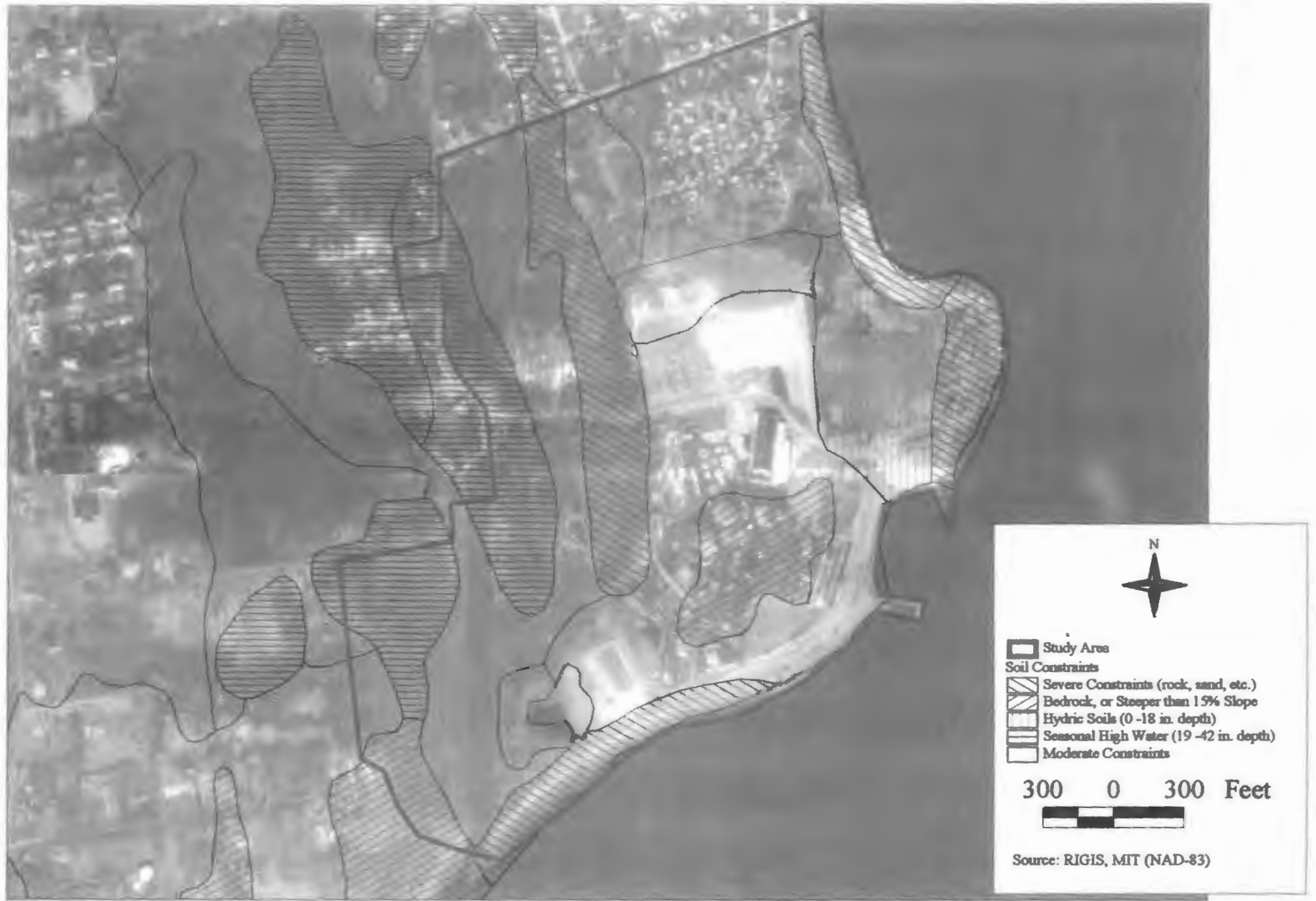

Figure 4. Rocky Point soil constraints 


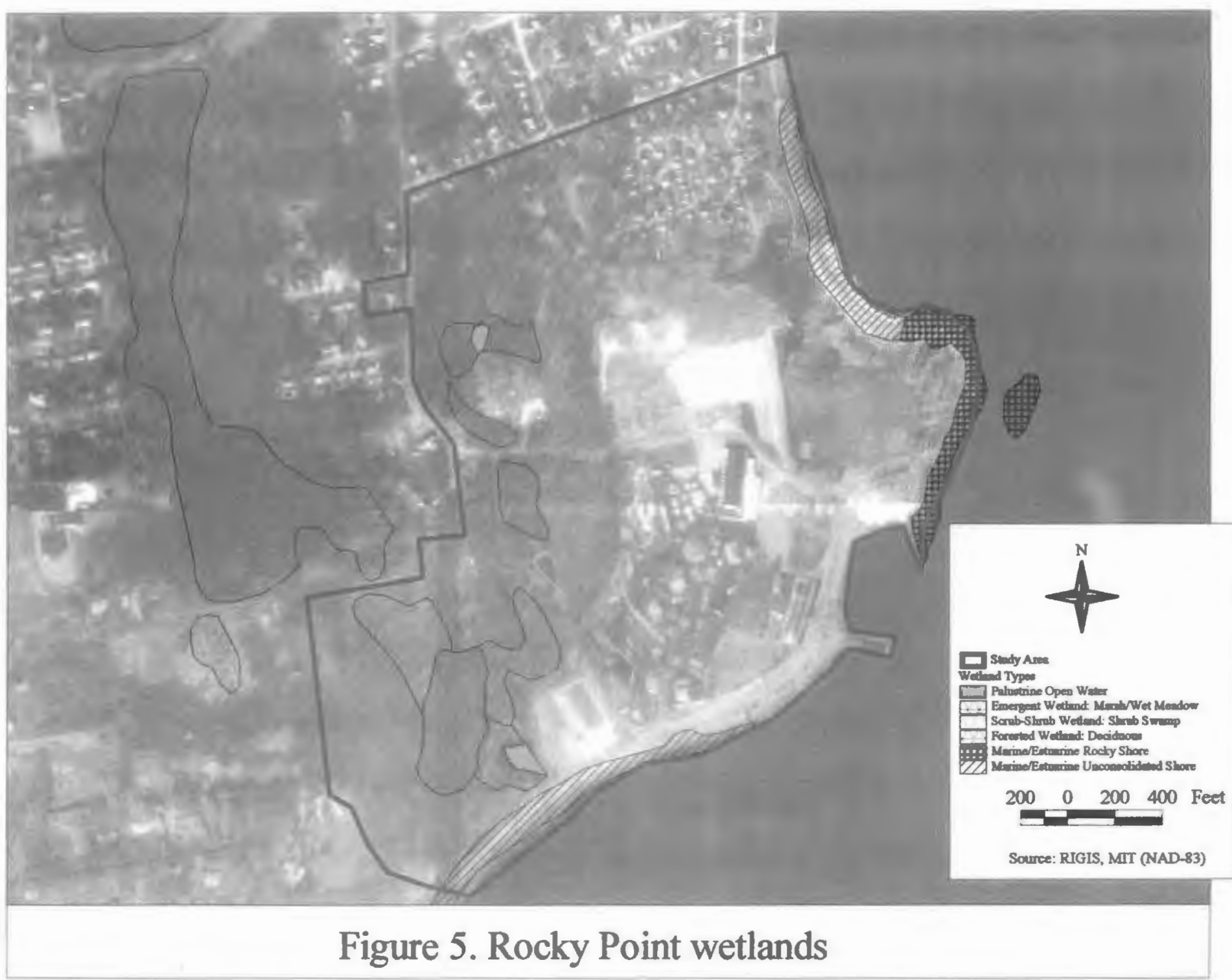




\section{Floodplain}

As it is a coastal site, the study area has an extensive area of floodplain. Figure 6 shows the areas of 100- and 500-year flood. It also shows the area of coastal flood with velocity hazard. This is the area where there is the potential for damage due to wave action. Flood-prone areas include low-lying portions of the site to the east and south. Floodplain, calculated using AutoCAD, accounts for roughly $1,787,681$ square feet of the study area, or 41 acres.

\section{Combined Environmental Constraints}

By overlapping maps of environmental features, we may assess the combined environmental constraints to development of the study area. Figure 7 shows the resulting constraints. Note that soil constraints due to seasonal high water, bedrock and steep slopes are not included, nor is the 500-year floodplain. These constraints are not judged to preclude many types of development; some of these areas in fact have previously been developed. Also note that the figure indicates areas where some types of development are strictly constrained, but not necessarily precluded.

The combined constraints account for roughly $2,987,243$ square feet, or 69 acres of the site. The constrained areas are primarily on the west and east portions of the site. This leaves a area of roughly 56 acres with few environmental constraints to development. 


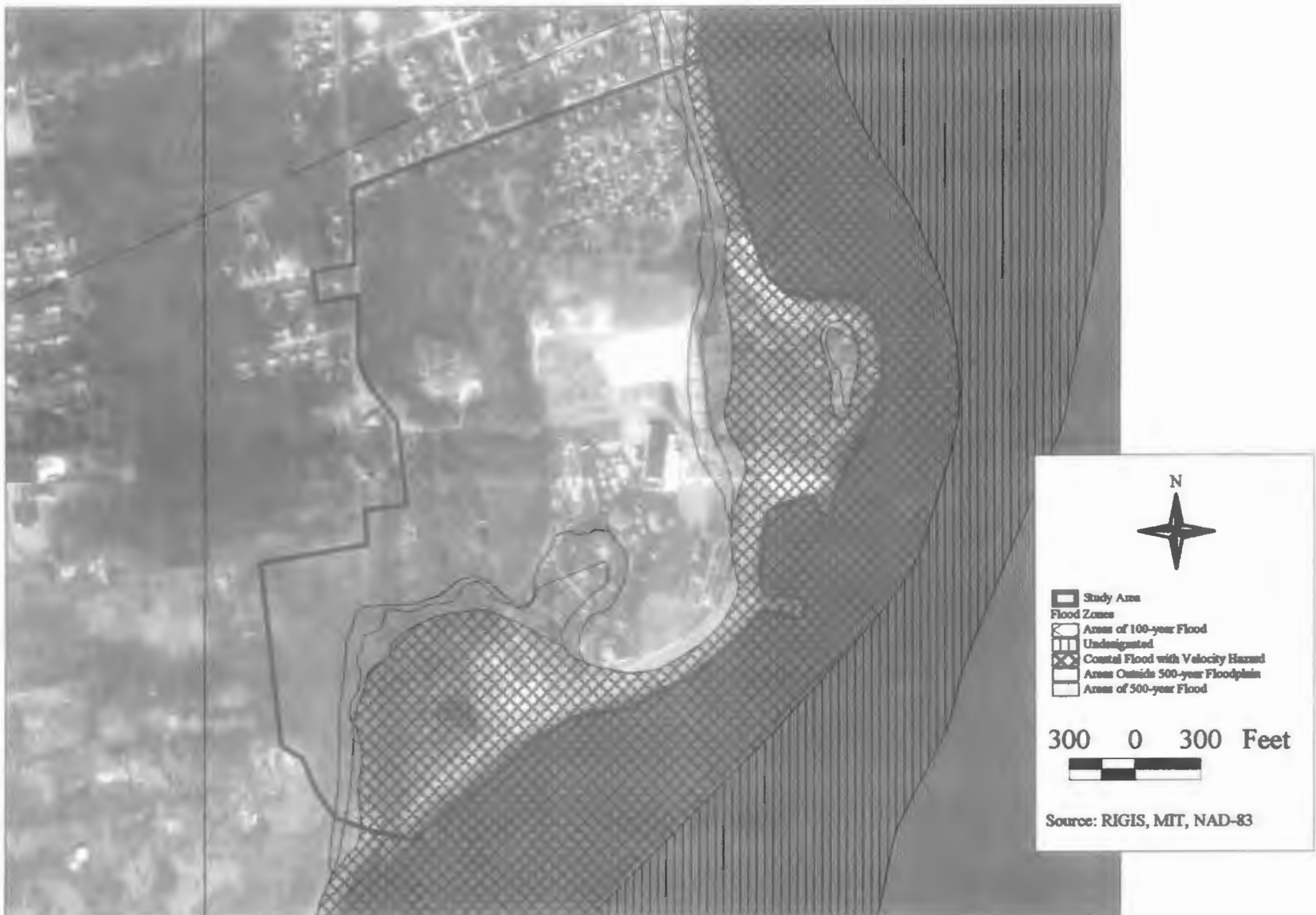

Figure 6. Rocky Point flood zones 


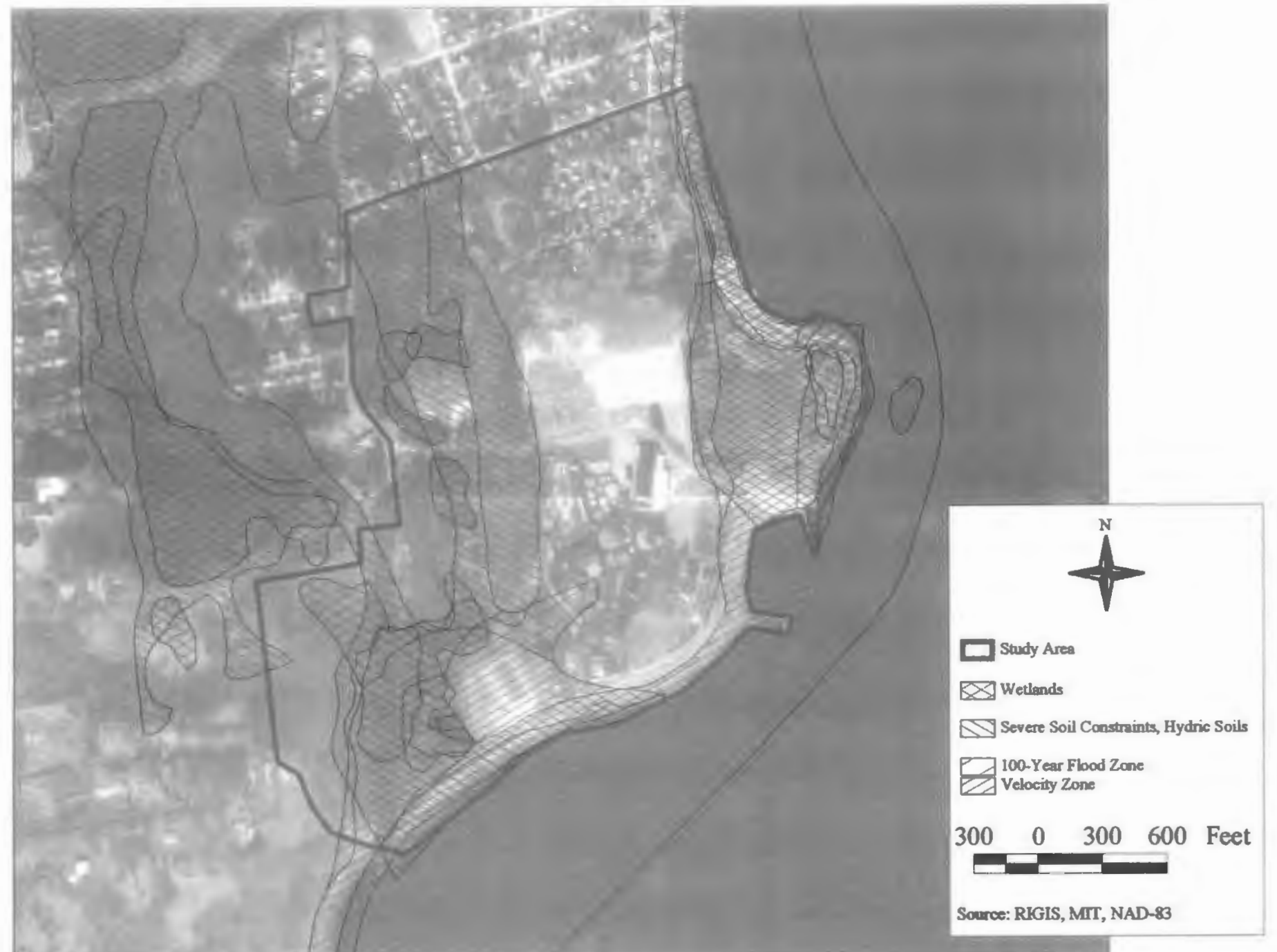

Figure 7. Rocky Point combined environmental constraints 


\section{Land Use and Infrastructure}

Land use in the vicinity of the study area is almost exclusively residential (Figure 8). To the north is Highland Beach, a dense single-family neighborhood. West and south of the property are the lower-density neighborhoods of Warwick Neck. There are few commercial uses currently in Warwick Neck. Among these are two golf course country clubs, a handful of small marinas in Warwick Cove and a convenience store on Warwick Neck Avenue. The Aldrich Estate, a mansion with acres of manicured grounds, owned by the Catholic Diocese and used for church purposes and private events, is just south of the study area. Commercial uses predominate on West Shore Road and Warwick Avenue, 1.5 miles to the north of the study area.

The study area is serviced by electricity, water, telephone and natural gas. There are no sanitary sewer lines in the study area. All structures are tied to individual sewage disposal systems (ISDS). There is, however, a sewer line that runs along Warwick Neck Avenue roughly 2,000 feet west of the entrance to Rocky Point. Warwick has plans to run a sewer line down Rocky Point Avenue to the entrance to the park. Any high-density redevelopment plan for Rocky Point should include a connection to this system.

For discussion purposes, the study are can be divided into four distinct areas (Figure 9): the former amusement park site (in Plat 380, part of Lot 1), undeveloped land (Plat 380, parts of Lots 1 and 3; Plat 379, Lots 8, 425, 426 and 445; and Plat 381, Lots 38, 39, 40 and 41), existing house lots (Plat 379, Lots 9, 158 and 159) and Rocky Beach (Plat 380, part of Lot 3 and Lot 281). 


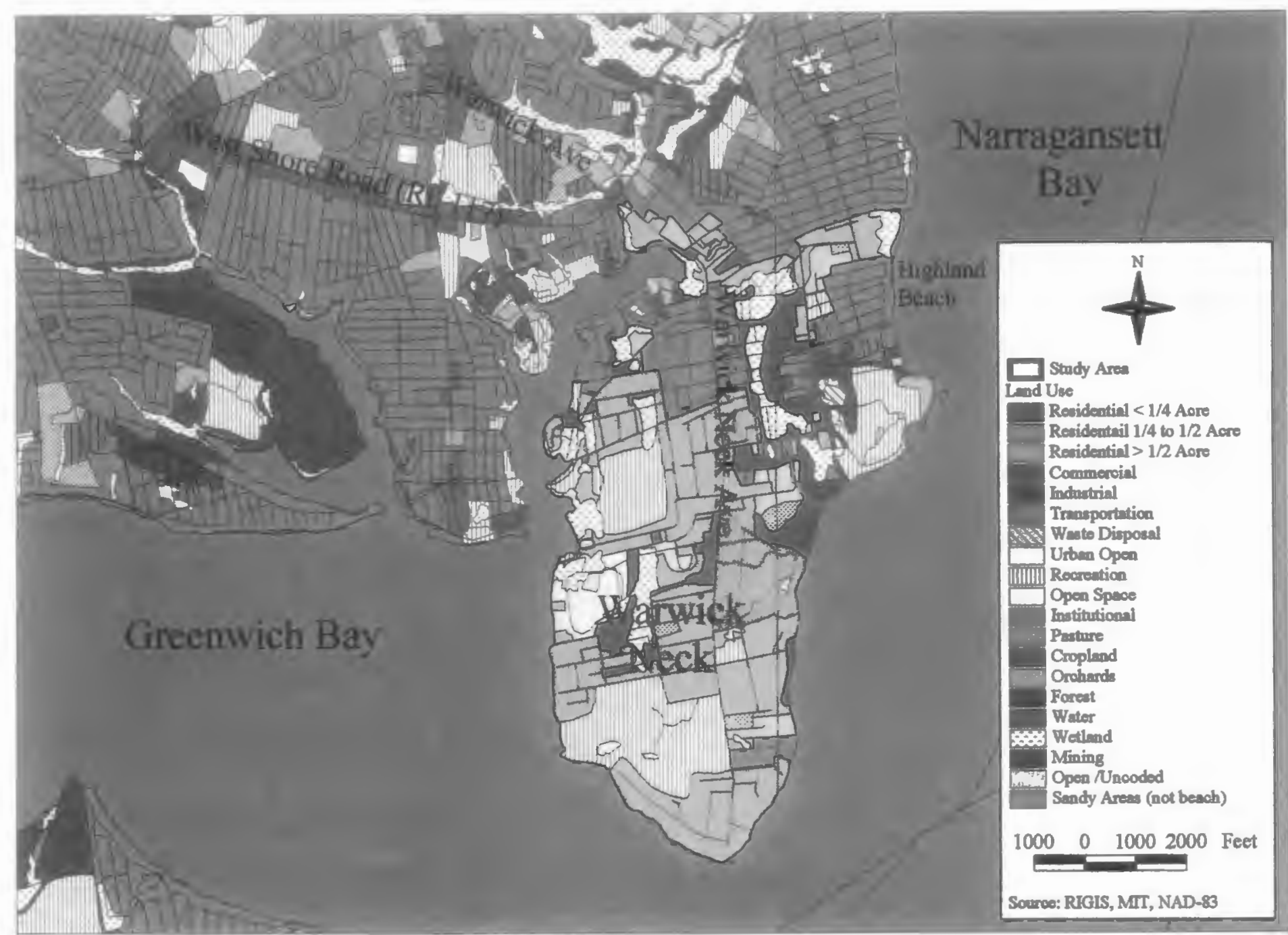

Figure 8. Land use in the vicinity of Rocky Point 


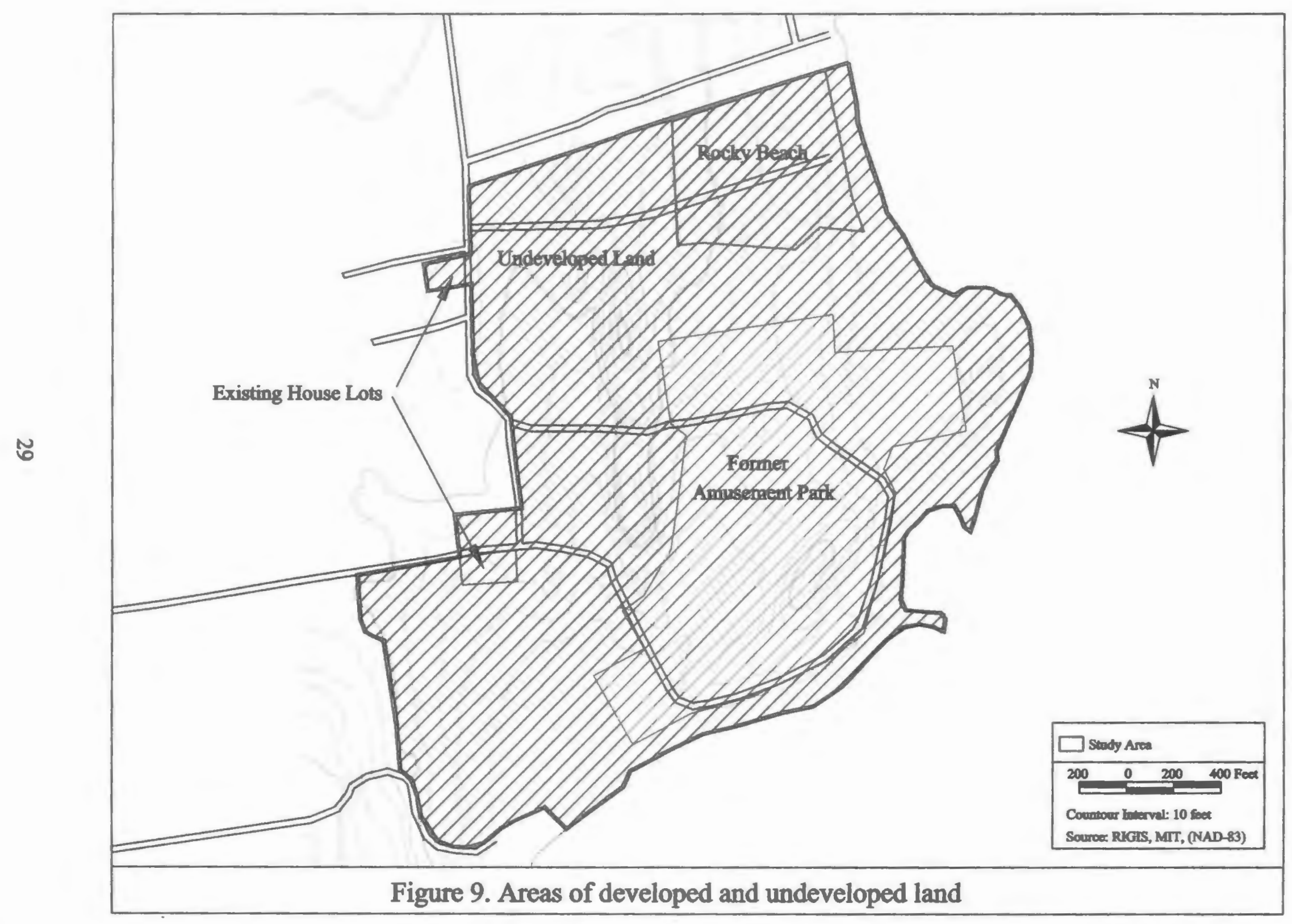


The Former Amusement Park Site

The land that makes up Plat 380, Lot 1 was formerly a place of many uses. It was the site of the amusement park, the Shore Dinner Hall, the Cliff House Lounge, the Palladium and Windjammer function halls, the pier, the ball field and the saltwater pool. Today, it is vacant and inaccessible to the public. What remains is an echo of its past.

This area is accessed from the corner of Rocky Point Avenue and Palmer Avenue. The private one-way road into the property runs east then north along the coast, curves to the west, and exits onto Palmer Avenue, some 500 feet north of the entrance. The road encircles the park midway.

The former midway is a relatively flat area that is entirely paved (Figures 10-13). The foundations of many of the former amusement park rides still stand, as do the shells of some of the carnival structures. Several buildings are also intact: the Cliff House in the southern portion of the midway, the Shore Dinner Hall to the east (Figure 14), and the Palladium/Windjammer complex (Figure 15) to the north. On a rock outcropping high above the Shore Dinner Hall stands Rock Cottage, a house that is visibly in a state of disrepair. North of the midway is a paved parking lot, roughly 6 acres in size (Figure 16). East of this is a field formerly used for baseball (Figure 17). The pier juts out into the bay, just south of the Point. It has been severely damaged by storms in the past several years (Figure 18). Southeast of the midway is the site of the former saltwater pool. The pool has been filled; all that remains is the outline of its foundation. North of the access road, near the exit of the park, is the former landfill for the park. It is not known if the soil in this area has been contaminated with hazardous materials. 


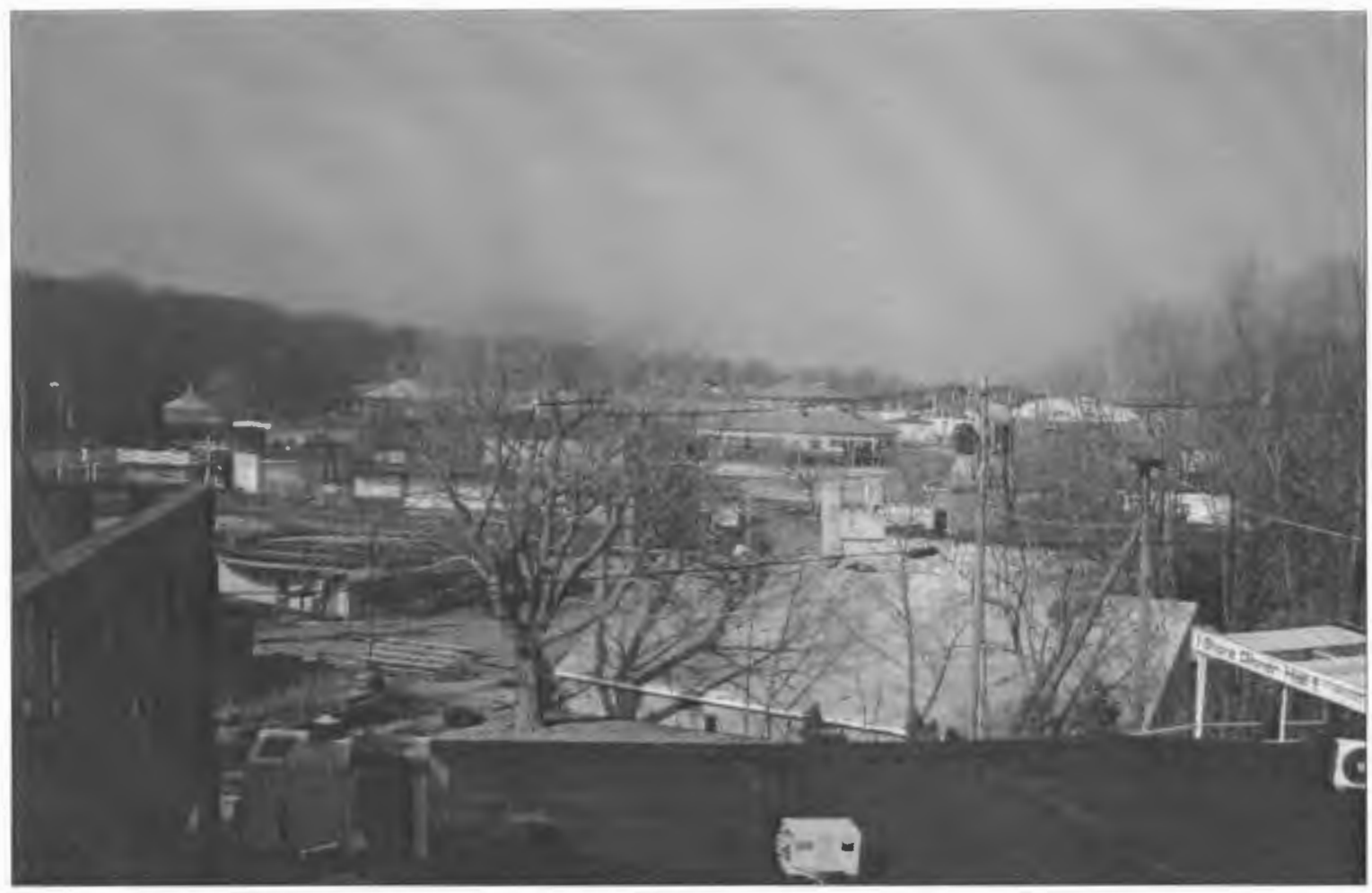

Figure 10. Rocky Point Midway looking north

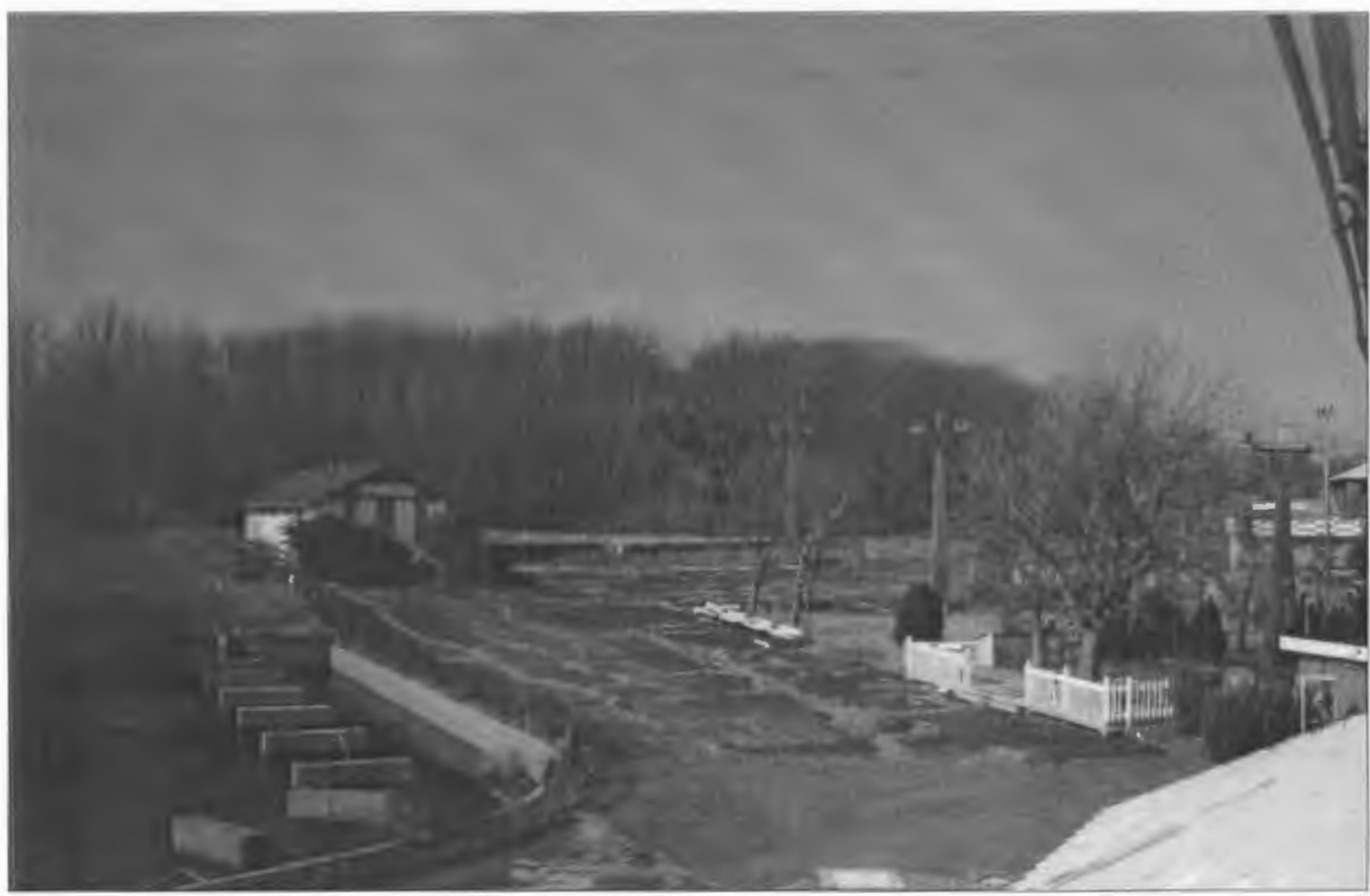

Figure 11. Midway looking west 


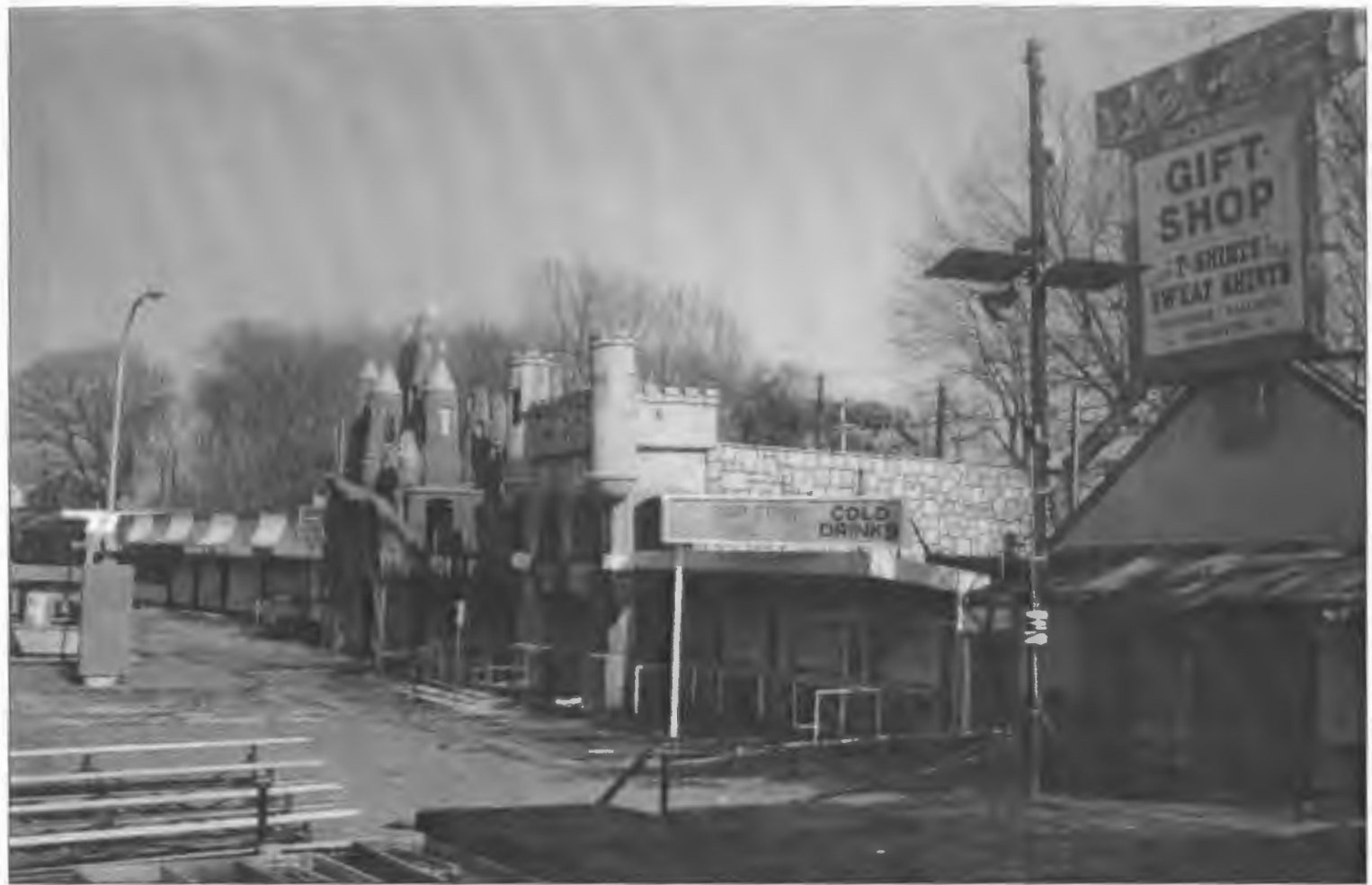

Figure 12. Abandoned amusements and concession stands

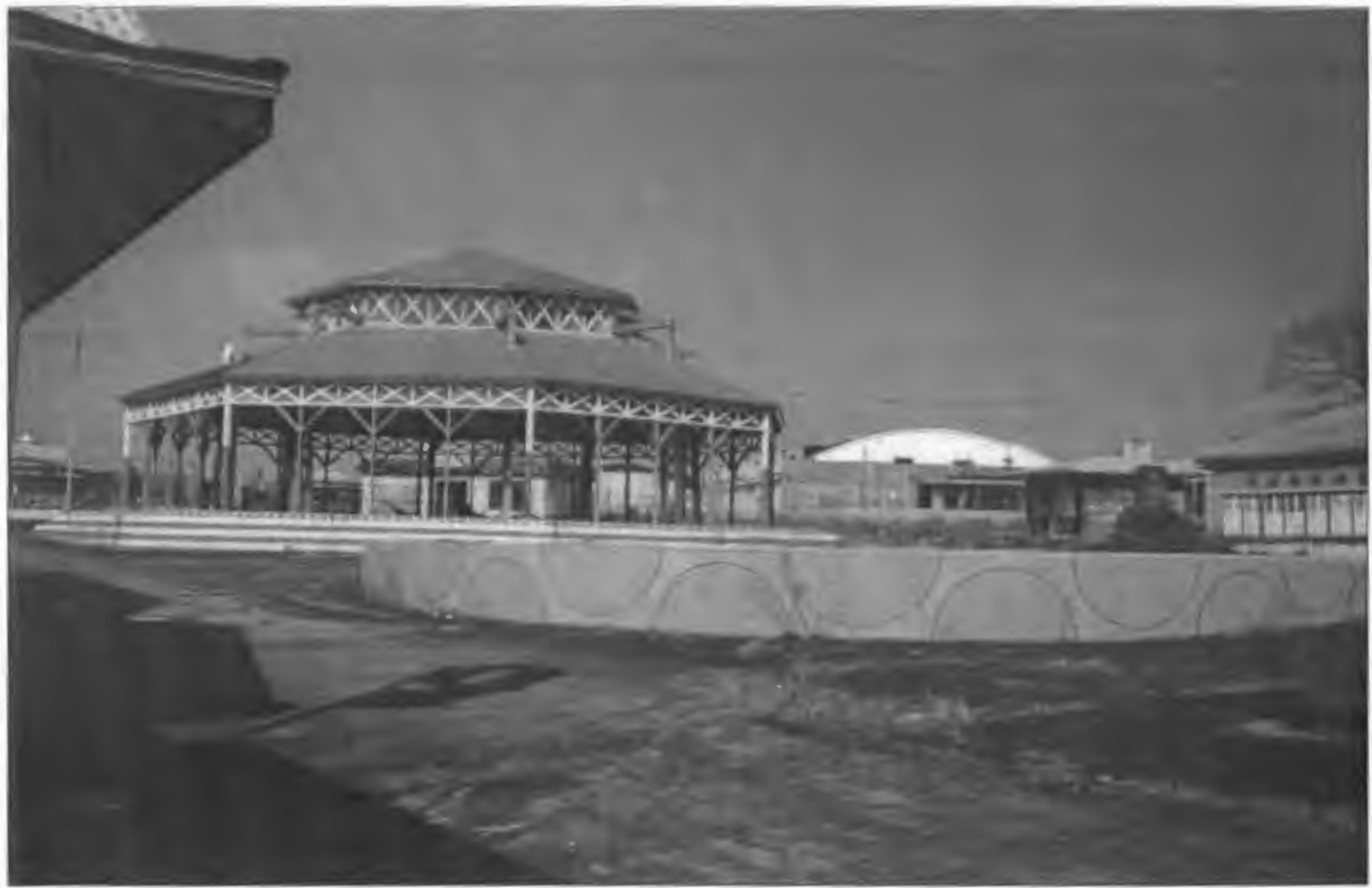

Figure 13. Carousel structure with Palladium in back to the right 


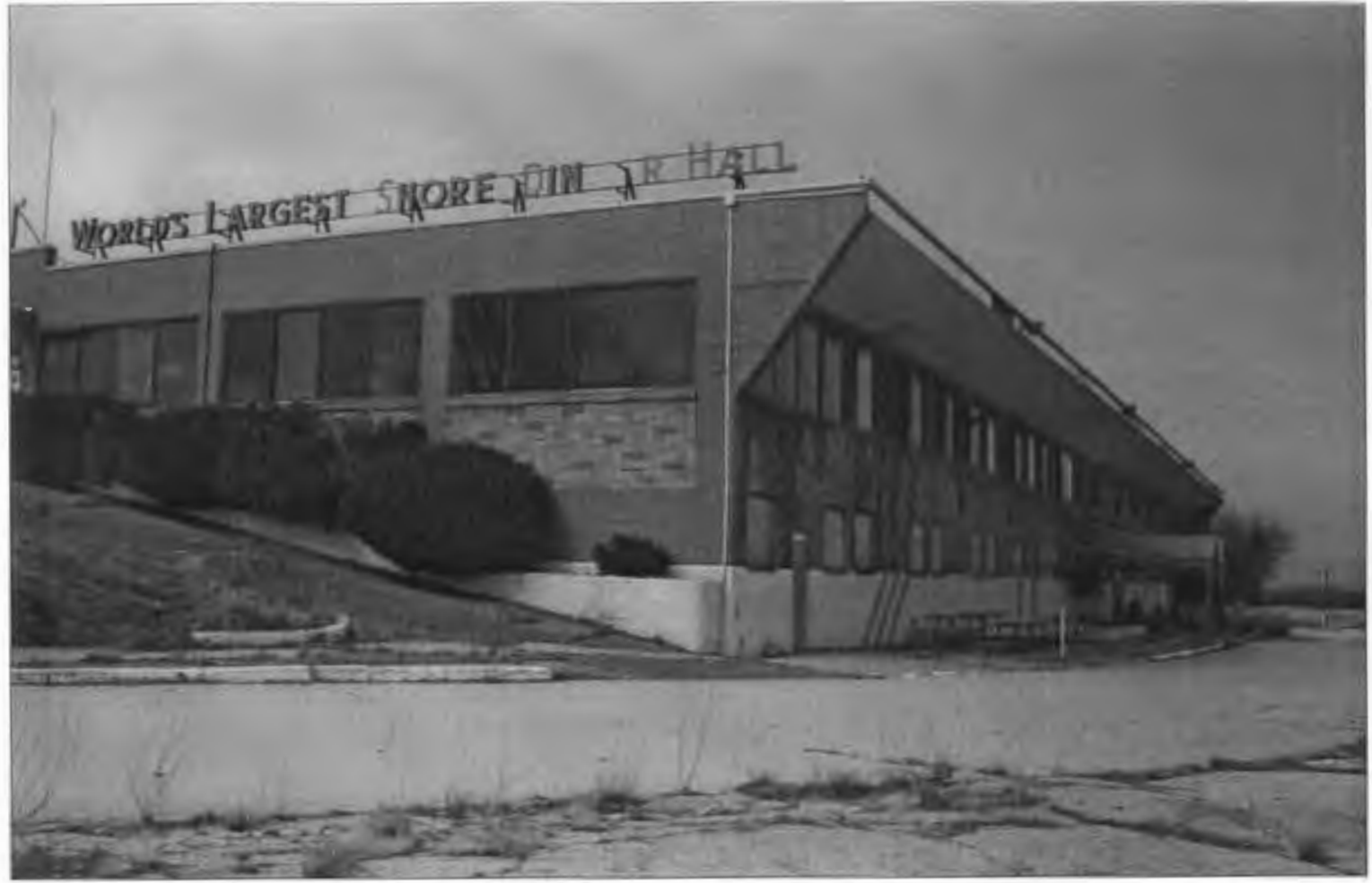

Figure 14. Shore Dinner Hall

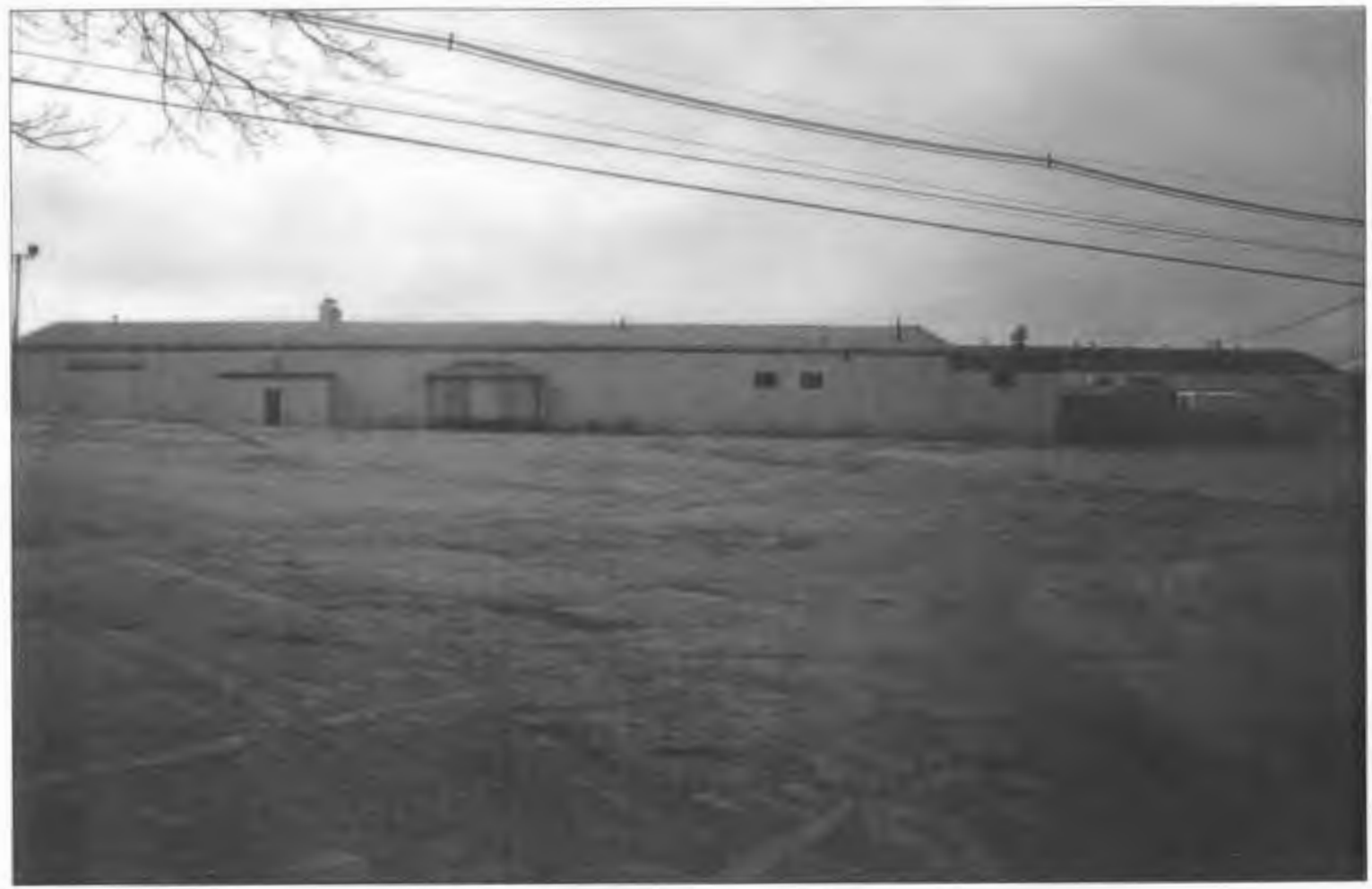

Figure 15. Windjammer/Palladium Complex 


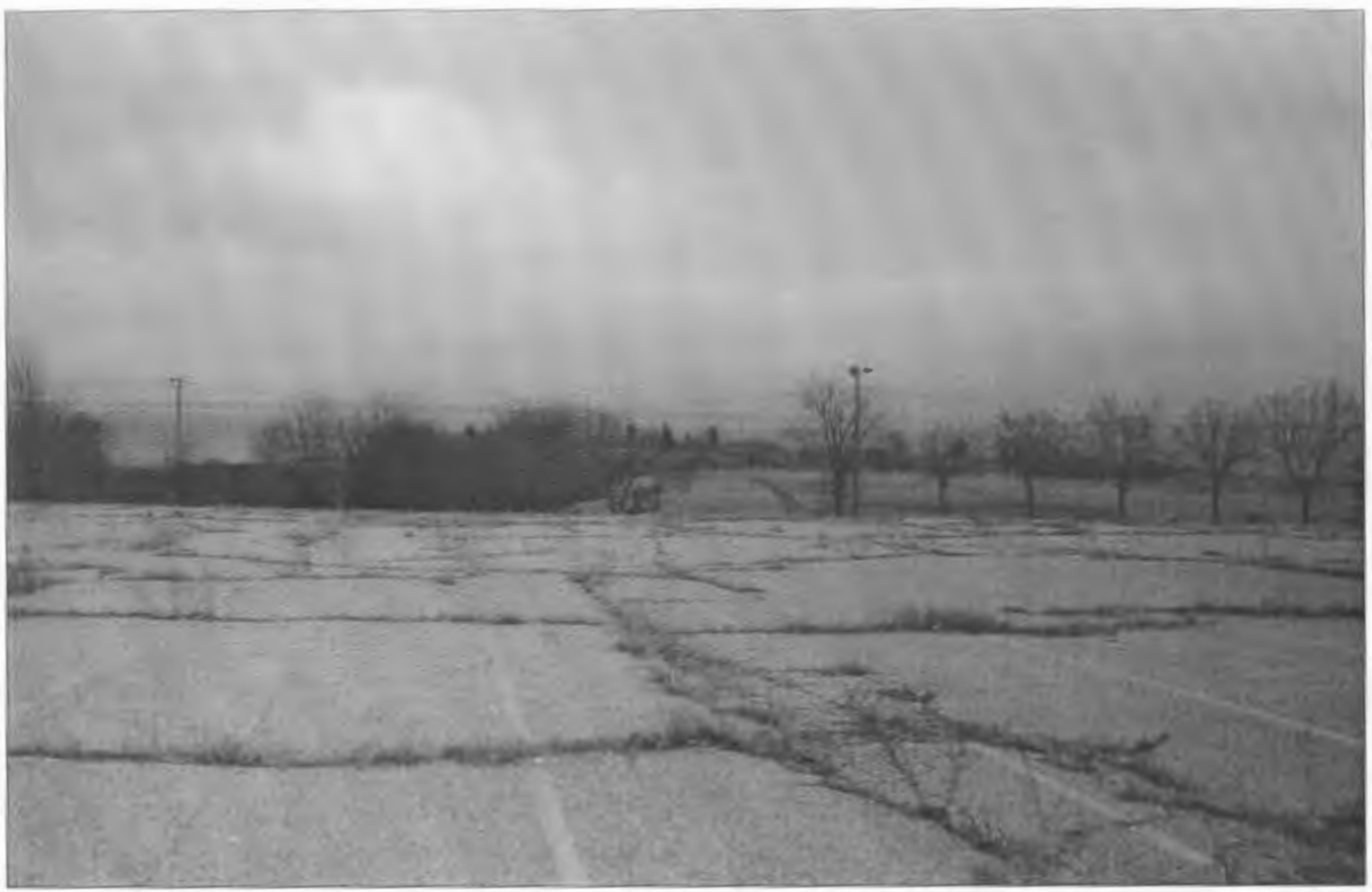

Figure 16. North parking lot

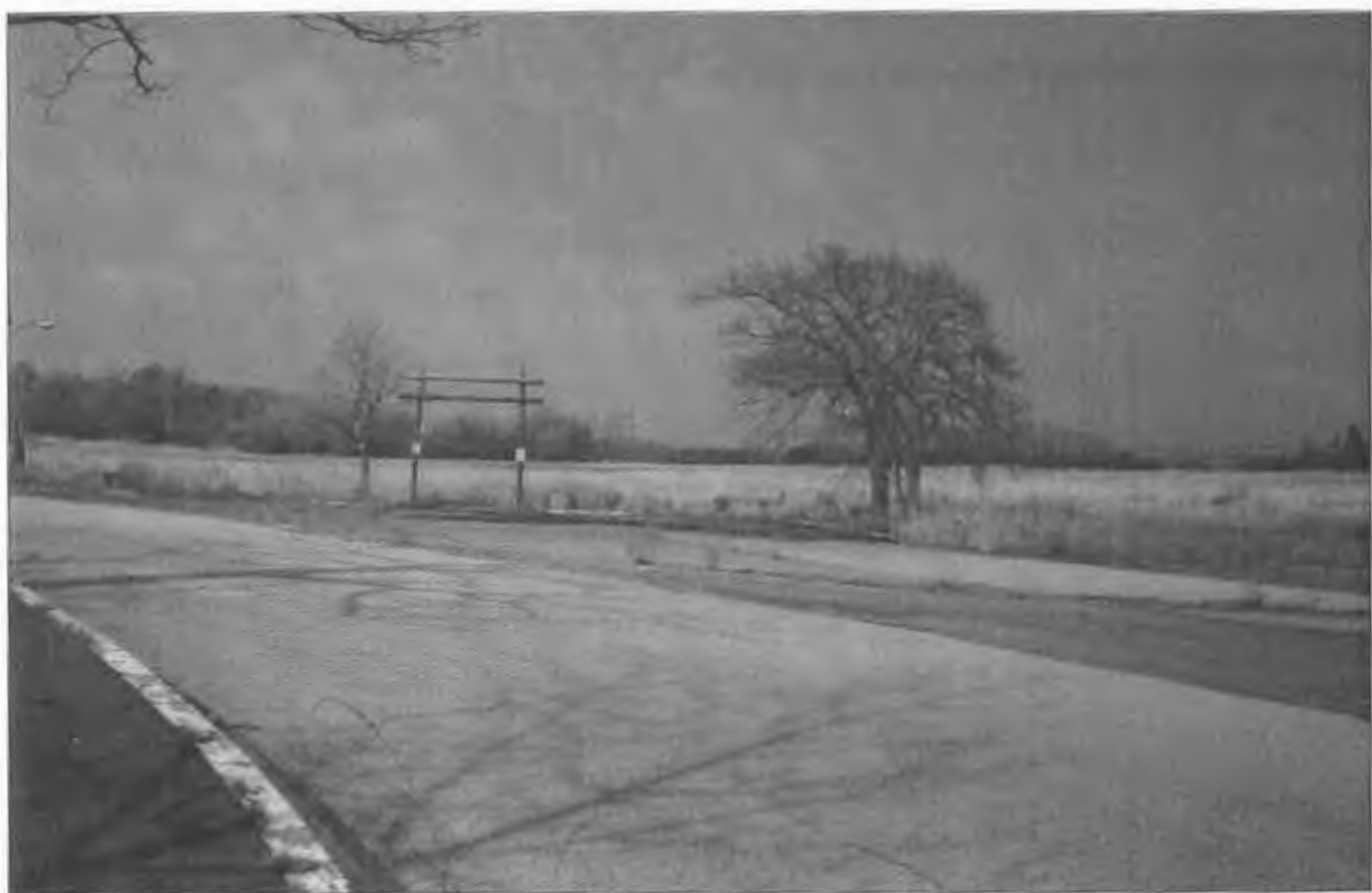

Figure 17. Former ball field 


\section{Undeveloped Land}

Much of the study area is undeveloped land. It consists primarily of steeply sloping woodland and wetland in Plats 380 and 381, west of the former amusement park and the Rocky Beach area. In this area is the aforementioned ridge that rises to the highest point in the study area, 100 feet above sea level (Figure 19), and affords sweeping views of Narragansett Bay and beyond. This contiguous area is roughly 56 acres in size. Also undeveloped are the sandy beaches in the north (Figure 20) and south portions of the study area, portions of Rocky Point that feature rock outcroppings and brushland, and an open field north of the north parking lot. This adds roughly 16 more acres that are undeveloped.

Existing House Lots

Three parcels are developed for single-family homes. Plat 379, Lot 9 contains an abandoned house (Figure 21). Lots 158 and 159 are contiguous, and are located at the intersection of Palmer Avenue and Boyleston Street. Lot 158 is vacant; Lot 159 contains a rented single-family house.

\section{Rocky Beach}

North of the former amusement park is the area known as Rocky Beach. This is home to approximately 70 cottages, the owners of which rent the land. This development is a relic of the era of seasonal coastal communities in Warwick. Rocky Beach is accessed from Palmer Avenue by Rocky Beach Avenue. The cottages are tightly 


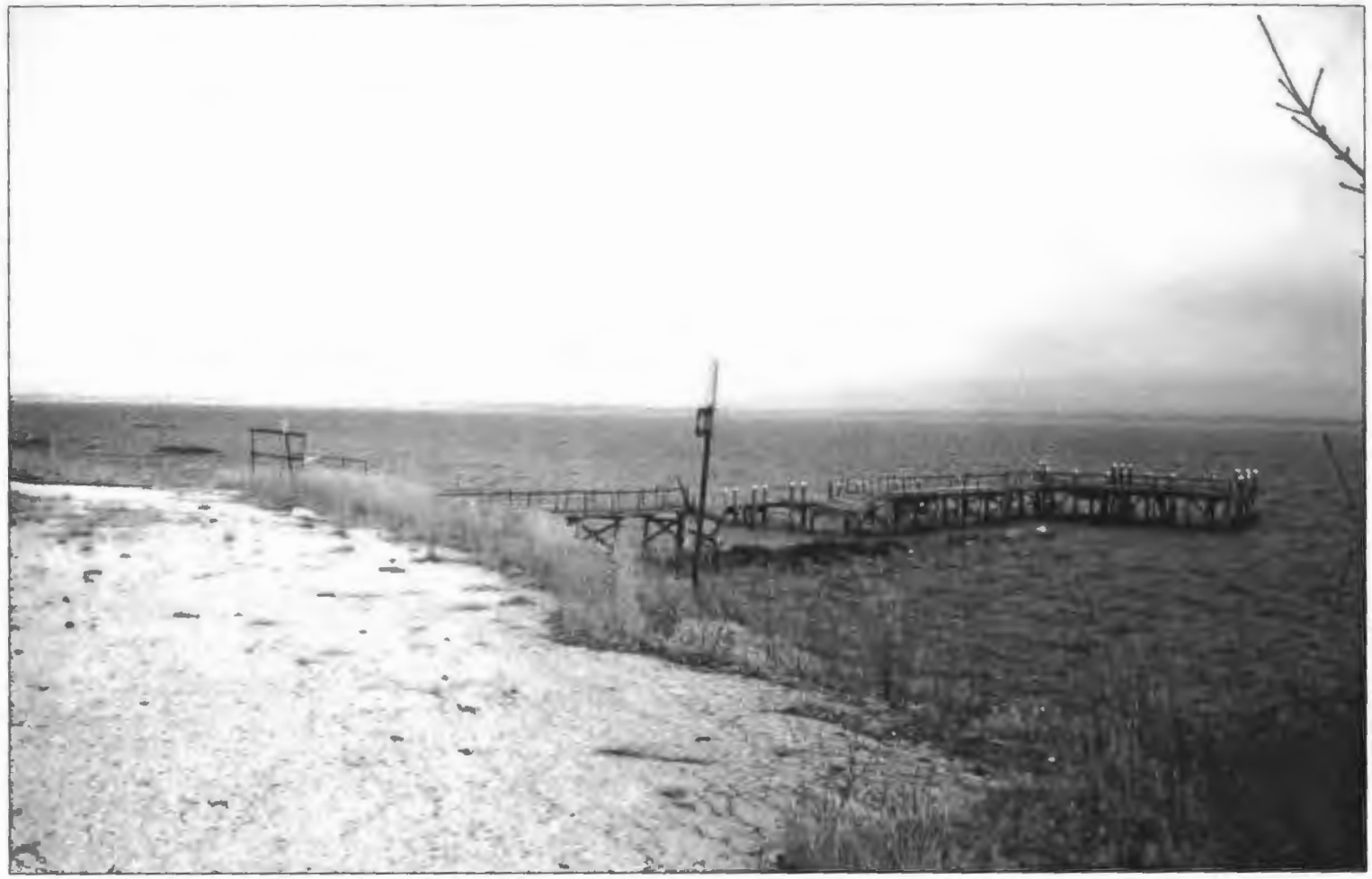

Figure 18. Rocky Point's Pier

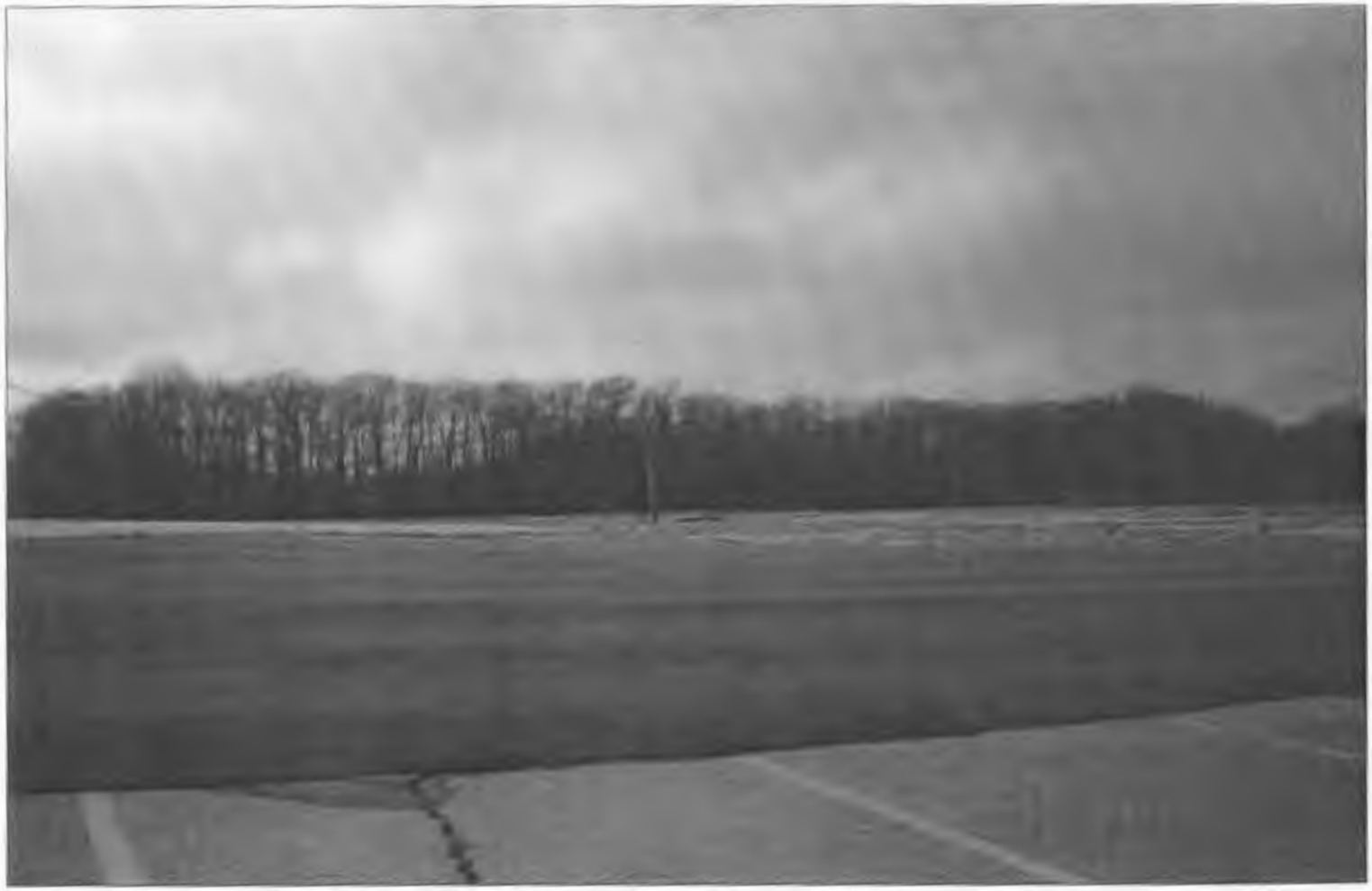

Figure 19. North parking lot looking west to the ridge 


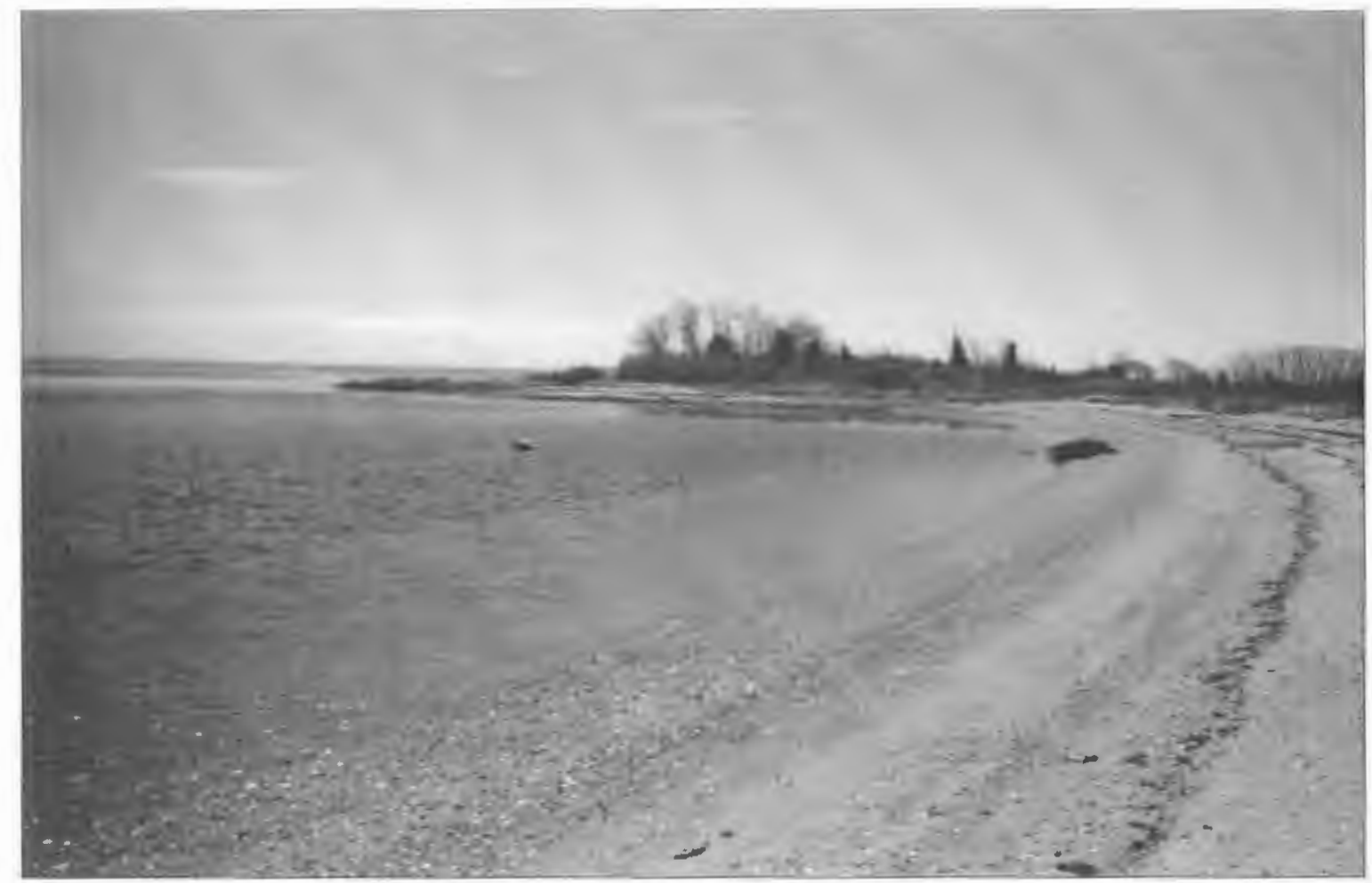

Figure 20. Sandy beach looking south to Rocky Point

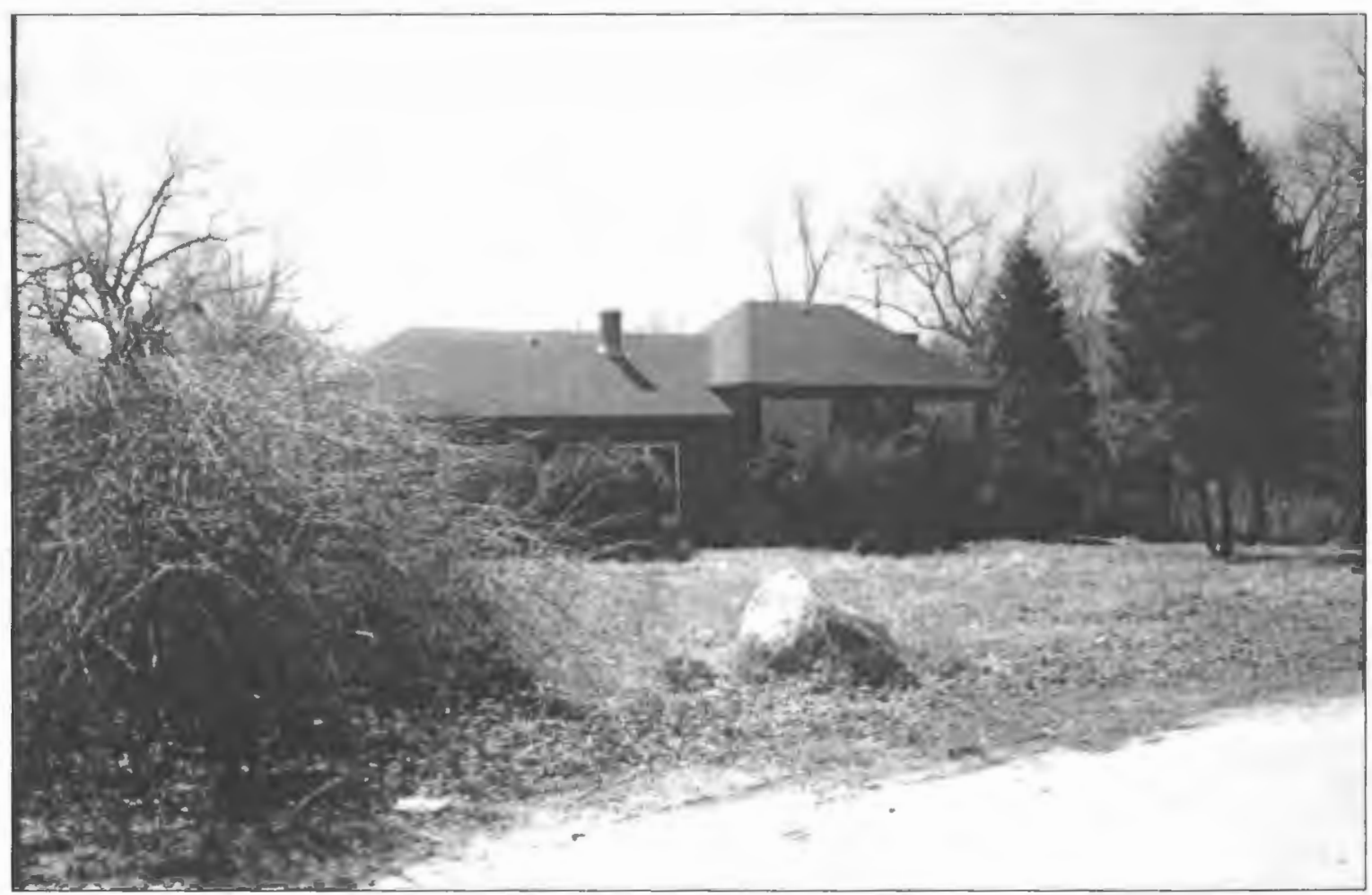

Figure 21. Abandoned house 
clustered together (Figures 22 and 23). Most are used during the summer, but there is evidence of year-round habitation in a few of the dwellings.

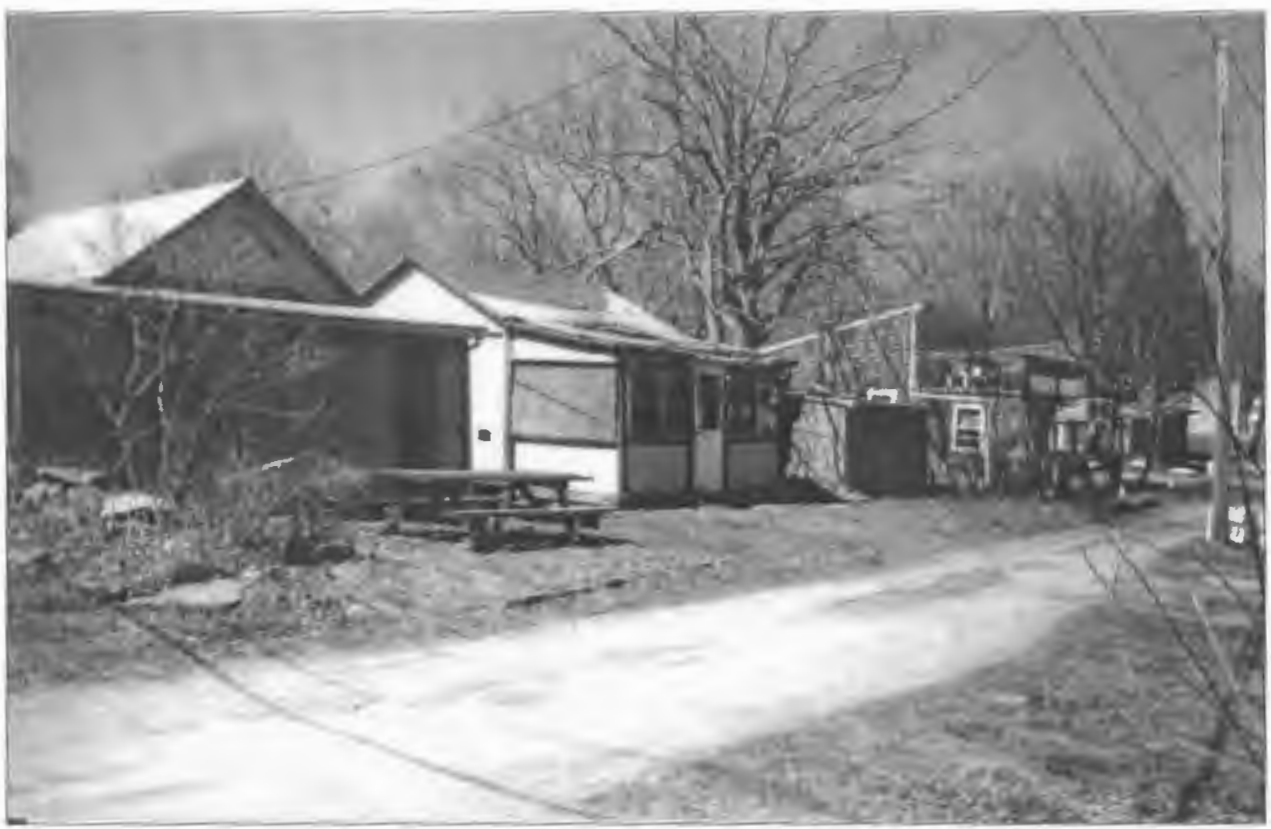

Figure 22. Rocky Beach cottages

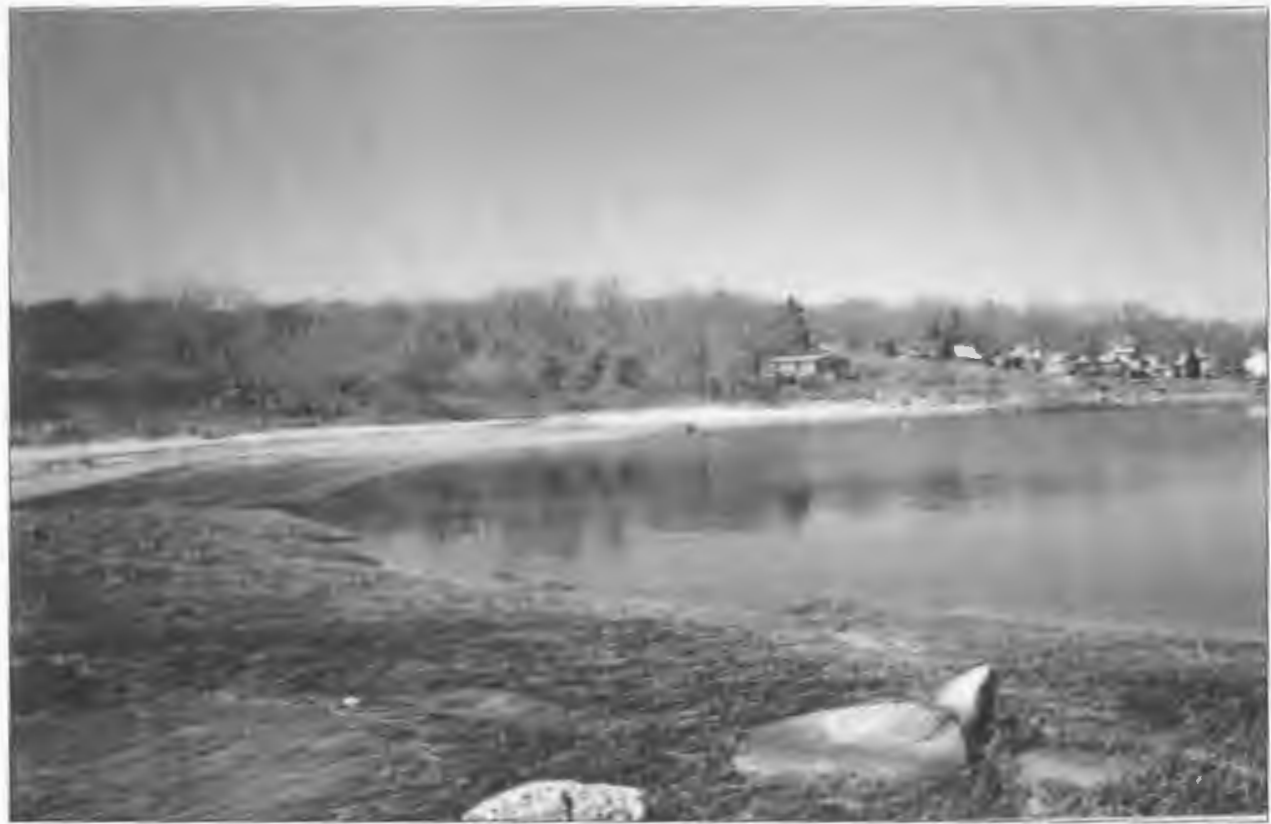

Figure 23. Sandy beach looking north to Rocky Beach cottages 


\section{Chapter Four}

\section{Regulatory and Political Setting}

\section{Introduction}

The environmental features described in the preceding chapter are significant to this study not just because of the ecological importance of areas of the property, or because of their tendency to make land development more difficult. They are also significant because federal, state and local laws regulate the way in which development may happen in or near environmentally sensitive features. The legal structure constraining development consists also of laws and ordinances, such as zoning and subdivision regulations (both of which must be consistent with a community's comprehensive plan), that regulate land use in the interest of the public's health, safety and welfare.

Should a developer demonstrate that a development plan is compliant with all applicable land development regulations and secure all necessary permits, building may proceed. However, in many cases, relief from one or more of the regulations is necessary to achieve a desired result; the developer must request variances or changes in ordinances from lawmakers or regulators. When this happens, the public may become involved to comment on the development. Any developer seeking regulatory relief would be wise to understand the politics involved in this process.

Because of Rocky Point's current zoning and its considerable environmental constraints, a change in the allowed land use for the property would almost certainly be necessary for any development to be feasible. Due to its size, potential impacts to the 
community, history and cultural value to Warwick and the state, a proposal for change in use for the land would likely arouse public interest.

To understand the hurdles that must be overcome to redevelop Rocky Point, this chapter describes the regulatory setting to which land in Rhode Island in general, and Warwick in particular, is subject. It also describes the political setting that will inevitably affect the fate of any redevelopment plan.

\section{Regulatory Setting}

Land development in Rhode Island is regulated in several ways. Local ordinances and development regulations regulate land use, subdivision procedures, parcel size, road width and a host of other aspects of development. Because the study area contains freshwater wetlands and falls in part within the coastal zone, state-level regulations also apply. This section documents how laws and regulations will affect the way in which the land in the study area may be developed.

\section{Comprehensive Plan}

Rhode Island requires that all municipalities in the state prepare a comprehensive plan to be a general, long-term guide to the physical, social and economic development of the municipality (R.I.G.L. 45, chap. 22.2). State law also requires that communities develop zoning and subdivision regulations to implement the vision of the comprehensive plan. The regulations must be consistent with the plan (R.I.G.L. 45, chaps. 23, 24).

Should a proposed development not be consistent with the plan, either the development 
proposal would have to be modified by the developer, or the comprehensive plan would have to be modified by the city council for the development to proceed.

Several sections of Warwick's Comprehensive Plan (1993) are pertinent to development at Rocky Point. The Land Use Element of the plan, written when the park was still operating and designated for heavy commercial uses, specifically addresses the zoning of Rocky Point. Clearly planning for a time in the future when the park would no longer exist, this element calls for relatively low-density residential use for the property. However, it also allows for flexibility in development. In its Policy Recommendations section, the element states:

Designate the Rocky Point property for very low density and low density residential use. Extend the existing zoning boundary line to the north, separating the Heavy Commercial from Residential A-10 southerly to a point directly across from Rocky Point Avenue. This portion of the property should be designated for low density residential use. Designate the 200 -feet coastal area within this portion of the property for low density residential use as well. The remainder of the property should be designated for very low density residential use including the coastal area. A reuse of this property could utilize planned unit development, cluster development, and other techniques to best suit the large size and natural features of the site (p. 106). 
There are other issues in the Land Use Element that are of significance to Rocky Point redevelopment. Shore access is considered a priority: "New development along the coast should consider access to the shore for users of the total development and if possible, others in the vicinity" (p. 102). Protecting open space is mentioned as a priority in this element as well as in the Comprehensive Plan's Natural Resources, Open Space and Recreation Plan, which states that protected open space is in short supply in the area around Rocky Point. Under this element's Goals and Objectives section is a list of priorities for the City. These include "preserve and maintain fresh and saltwater shore public access points ... implement a program of open space acquisition ... protect remaining wetlands, open space and shoreline access ... [and] maintain high standards of urban design and aesthetics in public open spaces" (p. 49).

\section{Zoning}

Warwick's Zoning Ordinance (1995) regulates the way in which land may be put to use. It addresses such issues as land use (e.g. residential, commercial, industrial), lot sizes and the area of lots that may be used for structures. Under the current ordinance, the land in the study area is zoned to comply with the Comprehensive Plan. The land's current zoning is for single-family houses, with lots ranging in size from 10,000 square feet $(\mathrm{A}-10)$ to 40,000 square feet (A-40) (Figure 24). Under this zoning, commercial uses would be prohibited anywhere on the Rocky Point property, although it might be possible for an amusement park to operate as a legal, non-conforming use.

Section 501 of the zoning ordinance allows for a technique of residential development called "clustering." In areas zoned for single-family homes, the houses may 


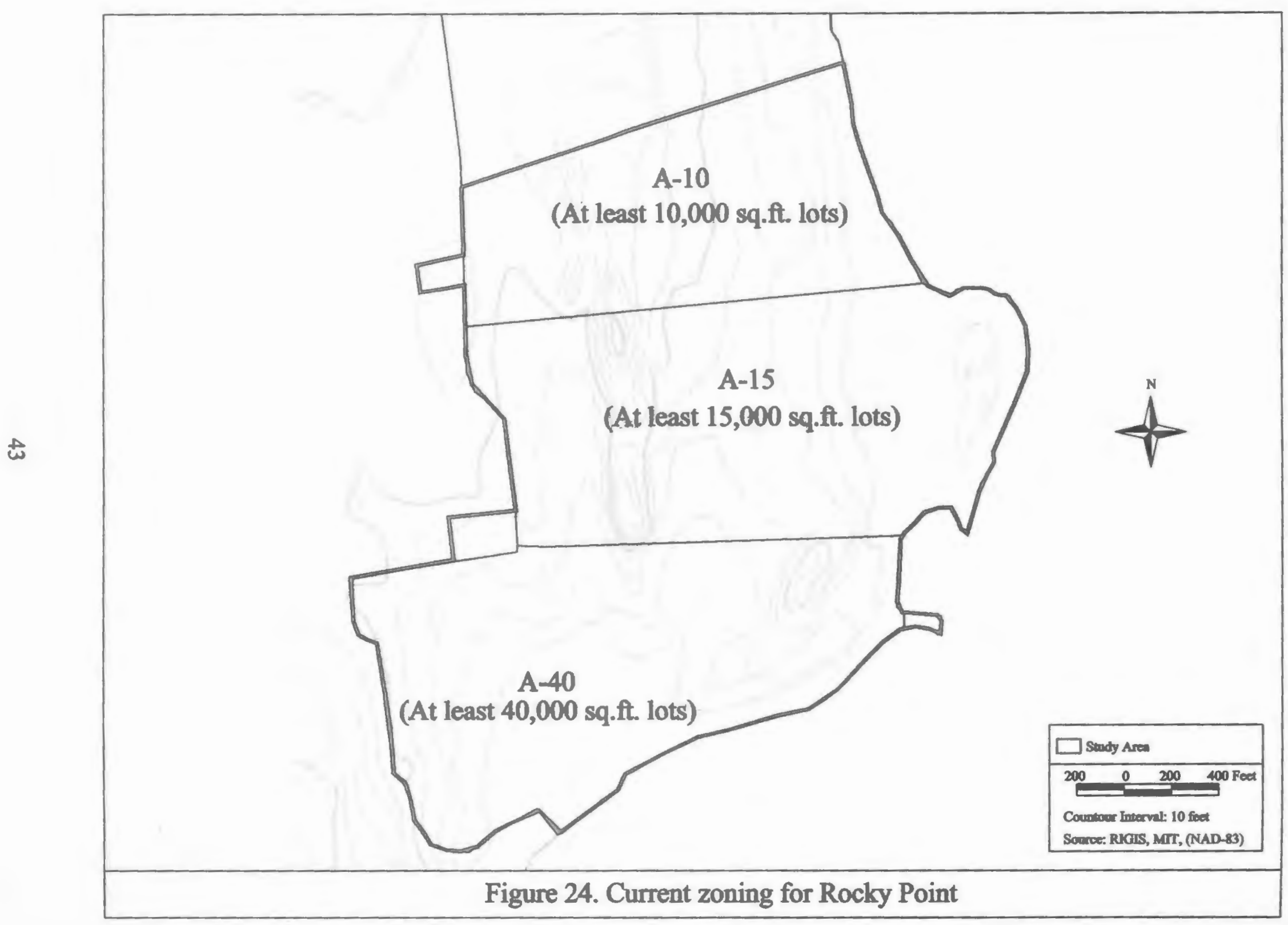


be placed on smaller lots with shorter setbacks than allowed by the conventional ordinance in order to preserve some of the developable land for common or public use. Minimum lot sizes may be made smaller as follows: in A-10 districts, from 10,000 square feet to 7,000 square feet; in A-15 districts, from 15,000 square feet to 9,000 square feet; and in A-40 districts from 40,000 square feet to 17,000 square feet. When the cluster technique is applied, the overall housing density of the development cannot change. The ordinance specifies the minimum amount of land that must be left as common open space: in A-10 districts, 15\%; in A-15 districts, 20\%; and in A-40 districts, 30 percent. The Zoning Ordinance has provisions for creating overlay districts. These are areas that would accommodate special uses that are not specifically addressed in the ordinance. Such districts include Institutional-Educational (IE) for educational facilities and their attendant uses, Planned District Residential (PDR) for multi-family housing developments of more than ten dwelling units, and Planned Unit Development (PUD) for a mix of residential and commercial uses, or commercial and industrial uses.

Under the section for Residential PUD, the ordinance specifies that these types of projects are "eligible for consideration within all residential districts" (p. 46). In PUDs, it is permitted to mix residential with retail and/or office uses. Commercial uses may occupy no more than $25 \%$ of residential gross floor area (GFA). Industrial uses are prohibited in these districts.

Any overlay district must be established by an amendment to the Zoning Ordinance. For this to happen, a five-step process must be followed (Warwick, 1995): 
1. A pre-application conference must be held with the planning department in which written and graphic plans must be submitted for review and comment.

2. The planning board must review the plan and recommend it for approval. The proposal must be consistent with the comprehensive plan and the development review regulations.

3. The city council must amend the zoning plat to establish an overlay district.

4. A final site plan must be submitted to the building official, who then forwards the plan to the planning director for review.

5. The planning director must determine whether the proposal is in accordance with the zoning ordinance, the comprehensive plan and any modifications imposed by the city council, and must notify the building official of this determination. If there are any discrepancies, the plan must be brought into conformance.

Should a developer wish to alter the plan at any stage of this process, a new petition to the council may be required. An overlay district may be repealed by the city council if the developer has not received a building permit within one year of the zone change.

Development Review Regulations

Warwick's Development Review Regulations (2000), also known as subdivision regulations, establish the procedures that must be followed whenever existing building lot lines are adjusted, altered or changed and when new lot lines are created. The regulations 
specify three types of subdivisions: an "administrative subdivision," when lot lines are moved or lots not to be developed are created, a "minor subdivision," when five or fewer lots are created, and a "major subdivision," when more than five lots are created.

Also defined in the regulations is the "Land Development Project" (LDP), one or more lots one a site that are coordinated for a complex of uses. PUD and cluster are both classified as LDPs. LDPs are subject to a four-step process called "Major Land Development Review." A developer must submit a pre-application, a master plan, a preliminary plan and then a final plan to the planning board. During the process, the board must hold at least one public information meeting at the master plan stage and one public hearing at the preliminary plan stage. The planning board determines if the development plan is consistent with the comprehensive plan and the development review regulations.

During the review process, the board may require the developer to provide public improvements such as streets, lighting, landscaping, sewers and drainage systems. It may require impact statements including documentation of environmental, fiscal and traffic impacts. Should there be a significant impact, the board may require mitigation. One type of mitigation would be for the developer to dedicate open space to the city. The board may also require performance and maintenance guarantees to ensure that the subdivision proceeds as described in the development plans.

\section{Department of Environmental Management Regulations}

The Rhode Island Department of Environmental Management (RIDEM) regulates land development in several ways. The Freshwater Wetlands Act (1971) states that no 
freshwater wetlands shall in any way be altered without approval from director of the RIDEM. Alteration is defined as "activities which occur within or outside of freshwater wetlands which impact their natural character, functions and/or values" (RIDEM, 1998a: 2). These activities include filling, excavating and diverting flow into or out of wetlands. The director has the authority to deny approval should the alteration proposed not be in the best interest of the public. RIDEM also regulates the installation of septic systems and sewers (RIDEM, 1998b), The Rhode Island Discharge Elimination System Regulations (RIPDES), enforced by RIDEM, regulates runoff from construction sites when five or more acres of land are disturbed. When stormwater runoff is directed into a storm sewer system or into waters of the state, a permit must be obtained. Under these regulations, a developer is required to implement management practices to control erosion and sedimentation (RIDEM, 1993).

Any project that will likely impact the quality of waters of the state and/or activities that will likely cause or contribute to flow alterations of these waters must receive certification from RIDEM (RIDEM, 1997). To receive water quality certification, a developer must demonstrate that the project will not cause a diminishment in the quality of the water and will not violate State water quality standards.

\section{Coastal Resource Management Council Regulations}

The Coastal Resource Management Council regulates land within 200 feet of any coastal feature and freshwater wetlands in the vicinity of the coast (CRMC, 1996). In the case of Rocky Point, its entire shoreline is a coastal feature. Currently, its pier, portions of the access road, the Shore Dinner Hall and the Cliff House are within the coastal zone. 
Any modifications to these structures or new construction within the coastal zone will require assent from the CRMC.

\section{Army Corps of Engineers}

The federal Army Corps of Engineers enforces the Rivers and Harbors Acts of 1890 (superseded) and 1899 (33 U.S.C. 401, et seq.). Under this law permits are required to obstruct or alter any navigable water of the United States. Section 10 of the law covers construction, excavation, or deposition of materials in, over, or under such waters, or any work which would affect the course, location, condition, or capacity of those waters (33 U.S.C. 403). The Corps also enforces sections of the Federal Water Pollution Control Act, (also known as the Clean Water Act). Section 404 (33 U.S.C. 1344) requires a permit from the Secretary of the Army, after notice and opportunity for public hearings, for the discharge of dredged or fill material into waters of the United States. In many cases, permits or assents from CRMC and/or RIDEM will satisfy the requirements of the Corps.

\section{Political Setting}

Should any development plan conform to the development regulations and current zoning of the land, and be granted the necessary permits and assents from state agencies, there would be nothing barring a developer from implementing the plan. In the case of Rocky Point, however, it would be difficult to build a profitable development under the current zoning because of the $\$ 10$ million price tag of the property and the land's environmental constraints. A change in the zoning ordinance would likely be necessary to 
increase the density of structures or change the use of the land. To acquire a zoning change, one must enter the political realm.

Zoning changes are granted by the City Council and are subject to approval by the Mayor of Warwick. According to Warwick Councilman Carlo Pisaturo, issues of impact on city services will be paramount to the council. These include snow plowing, street lighting, road maintenance, sewer services and perhaps most importantly, tax revenue and impact on schools. Developers will likely have to demonstrate that the positive impacts to the city will outweigh the negative impacts. They would also have to show that the development would conform to the city's comprehensive plan.

The council and mayor are also subject to scrutiny by the public. Any redevelopment of this landmark property would be difficult without public acceptance, and the public is unlikely to support development that impacts them negatively. Even if the developers can demonstrate a minimal impact, haphazard development on this site that for many has sentimental value would likely be met with resistance.

A developer of this site should be prepared to face public scrutiny. It would be wise to involve the public early in the planning process and to consider changing the plan to address the concerns of interested parties. Rocky Point will not stand vacant forever; it will be redeveloped. The challenge is to redevelop it in a way that meets the needs of the people who will use it and of those who will be affected by its impact. 


\section{Chapter Five}

\section{Redevelopment Options}

\section{Introduction}

This chapter explores and evaluates options for the redevelopment of the land in the study area. Under the area's current zoning, single-family homes and open space would be the only available options. With changes in zoning, however, higher-density housing and commercial space could be possible. Redevelopment options are evaluated with respect to several criteria: consistency with Warwick's Comprehensive Plan, appropriateness for the environmental features and historic character of the site, return on investment of the development, relative impact to the city, amount of open space preserved, access to the shoreline, reuse of existing buildings and livability.

\section{Open Space}

One option is to convert the 125 acres in the study area to public open space. The property could be bought outright by the state, city, preservation groups, or a combination of all of these. The land would be purchased at market value (up to $\$ 10$ million) and be improved for use by the public. This option is consistent with the Comprehensive Plan as it contributes to Warwick's open space network and provides access to the shore for the public. Rocky Point would be a beautiful place for a park, and, depending on the open space uses to which the land would be put, the impact on the city due to services and traffic could be minimal.

This option is problematic, however, because it would involve substantial costs for improvements. There are dozens of acres of pavement and numerous structures all 
over the site that would have to be demolished at significant cost to taxpayers. It would also take years for the developed land to revert to a natural state that would be appropriate for a park. Rocky Point should have public parkland, but it should encompass the undeveloped areas, so that minimal expense would be required to improve the land. This option would also have no tangible return to investors; as public land, it would produce no tax revenue. While 125 acres would be a marvelous addition to a Bay parks system, the expense is high. Public money would be more wisely spent to preserve land that already has value as parkland, not on developed land that would have to be converted into parkland.

\section{Residential Development}

Single-family Homes

The current zoning of the study area (see Figure 24) allows for exclusively singlefamily house lots at low to medium density. This use is consistent with Warwick's zoning regulations and its comprehensive plan. Under this zoning, with severe environmental constraints (wetlands and flood velocity zone) subtracted, there are roughly 26 acres of A-10, 32 acres of A-15 and 25 acres of A-40-zoned land in the study area. Using the standard set in Warwick's zoning code, we deduct $25 \%, 20 \%$ and $10 \%$ of the land for

roads in the A-10, A-15 and A-40 zones, respectively. Under this scenario, there could roughly be 85 A-10 lots, 74 A-15 lots and 24 A-40 lots, for a total of 183 house lots.

This option would leave open the possibility of preserving some land for open space by using Warwick's single-family cluster district. The same number of houses would sit on smaller lots so that common open space could be made available. It also 
could provide for public access to the shoreline and rehabilitation of the pier for public use. With 183 new houses, the traffic impact to Warwick would not be terribly problematic. However, this type of development does not take full advantage of the outstanding characteristics of the site. It would require demolition of all existing structures to make way for house lots, so no reuse of the buildings would be possible. There could be no commercial uses for residents or visitors- much of the historic character of the Park would be lost. Depending on the number of children in the community and the assessed value of the property, there could be a net loss to the city of tax revenue due to the cost of schooling children. The return on investment of this development, due to the relatively low-density of dwelling units and the demolition of all the existing structures, would be better only than the option of buying the land for open space.

\section{High Density Residential}

Under Warwick's Planned District Residential (PDR) overlay zoning, multiplefamily housing, such as condominiums or apartment buildings, is possible. The current zoning allows for the maximum density of dwelling units per acre to be 9,6 and 3 for A10, A-15 and A-40 zones, respectively. Again, subtracting for severe environmental constraints and roads, A-10, A-15 and A-40 zones could accommodate 175, 153 and 67 units, respectively, for a total of 395 units.

All proposed plans for Rocky Point made public to date have attempted to use this type of overlay district, even though the Comprehensive Plan does not specify this use as an option for Rocky Point. With 395 units, this option will return more to an investor than 
would a single-family development. The option could also provide for a significant amount of open space preservation, shore access and the reuse of existing buildings as living spaces. As with the single-family option, however, there would be no provision for commercial space. The impact of this development on traffic, especially because there would be no place for the residents to shop within walking distance of the housing, would be significant.

The net effect on taxes would depend on the value of the properties and to whom the units are sold. As a community of empty-nesters, the burden on city services would be lower than it would for a community of families. Even so, if there are half the number of children in a 395-unit condominium development than in a 183-unit single-family development, the burden on educational services would be roughly the same.

\section{Mixed Use Village}

The option of mixed use combines residential, commercial and open space uses in the same development. Under Warwick's zoning regulation, this type of development can occur in a Planned Unit Development (PUD) zone. The Comprehensive Plan suggests that this type of use could be appropriate for Rocky Point.

A mixed use village is reminiscent of the historical uses of the park, as it provides for residential, commercial and recreational uses. Under the PUD zoning overlay, even amusement park rides, such as a carousel, would be possible. PUD also allows for the rehabilitation of existing buildings for commercial, residential or both uses. A balance can be struck between many uses. A PUD will ensure that the most scenic land is preserved and that the appropriate land is developed. It will guarantee that the public will 
have access to the community to shop, recreate and use the shoreline. It will provide for a residential development that will have less impact on educational services than using the whole study area for residences since the tax burden will be shared by residential and commercial uses.

\section{Conclusion}

Rocky Point has, for nearly 160 years, been intensively developed for recreation, commercial and residential uses. This mix of uses is still appropriate for the site. There exists too much infrastructure to convert the land entirely to open space. To use it for exclusively high or low density residential property is also inappropriate because this would limit public access to the land and have no commercial uses, two of the outstanding features of the former park. Redevelopment of Rocky Point should be done in a manner that is respectful and reminiscent of its past uses, but that incorporates sound planning principles and meets modern-day needs. A mix of uses accomplishes these goals. 


\section{Chapter Six}

\section{A Redevelopment Plan for Rocky Point}

\section{Introduction}

A mix of commercial, residential and recreational/open space uses has been concluded to be the best option for redevelopment of Rocky Point. This type of development can be accomplished through Warwick's PUD overlay district. This chapter describes the New Urbanism principles for integrated, mixed use developments. Next, these principles are applied to the land in the study area. The redevelopment plan provides for open space with active and passive recreation, commercial, residential and transit uses. Concept plans, suggestions for rehabilitation of structures, urban design guidelines and discussions of utilities and demolition are also included.

\section{Mixed Use, PUD and the New Urbanism}

Principles of the urban design movement known as the "New Urbanism" are appropriate to the design of a mixed-use village. The movement, active since the 1980 s, aims to address many of the problems associated with "sprawl" patterns of suburban development that arose in the U.S. following World War II (Katz, 1994, Duany, 1991). Low-density development is seen as creating a fragmented society, damaging the environment and making people dependent on the automobile to go anywhere. New urbanists call for sustainable development patterns that are reminiscent of pre-war urban communities. A mix of housing, civic, recreational and commercial uses enables residents of a community to walk, rather than drive to a separate zone, to shop, work or 
recreate. A relatively dense development pattern encourages people to interact and preserves open space. A mix of housing sizes and architectural styles includes singleand multi-family houses and apartment buildings, and retail buildings that feature apartments on upper floors. This mix accommodates people of diverse income levels and promotes an aesthetically pleasing community. These concept can be applied both to infill development in existing cities and suburbs and to the channeling of new growth at the edge.

The prototypical New Urbanist community is Seaside, located in the Florida panhandle. A local example of the types of residential design features used in Seaside is Wickford Point in North Kingstown, Rhode Island (Figure 25). Note that the houses are clustered close to each other to preserve open space. They have shallow setbacks from the street and the garages are placed to the rear of the lots to provide an attractive streetscape. Sidewalks encourage pedestrian traffic through the neighborhood. Perhaps the best example of a mixed-use district in Rhode Island is found in the village of Wickford (Figure 26). The buildings have no setback from the sidewalk to encourage window-shopping. Retail or office uses predominate on the ground floor, with residences on upper floors. This type of design is common in New Urbanist communities.

According to Andres Duany and Elizabeth Plater-Zyberk, the ideal size of a village is $1 / 4$ mile from the center to the edge (Katz, 1994). This enables people at the outskirts of the development to walk to the center in less than five minutes. The majority of people, according to Duany, will drive to get to a location farther than a five-minute walk. The New Urbanism also encourages the use of public transportation. In what he calls Pedestrian Pockets, or Transit-oriented Development (TOD), Peter Calthorpe (1993) 


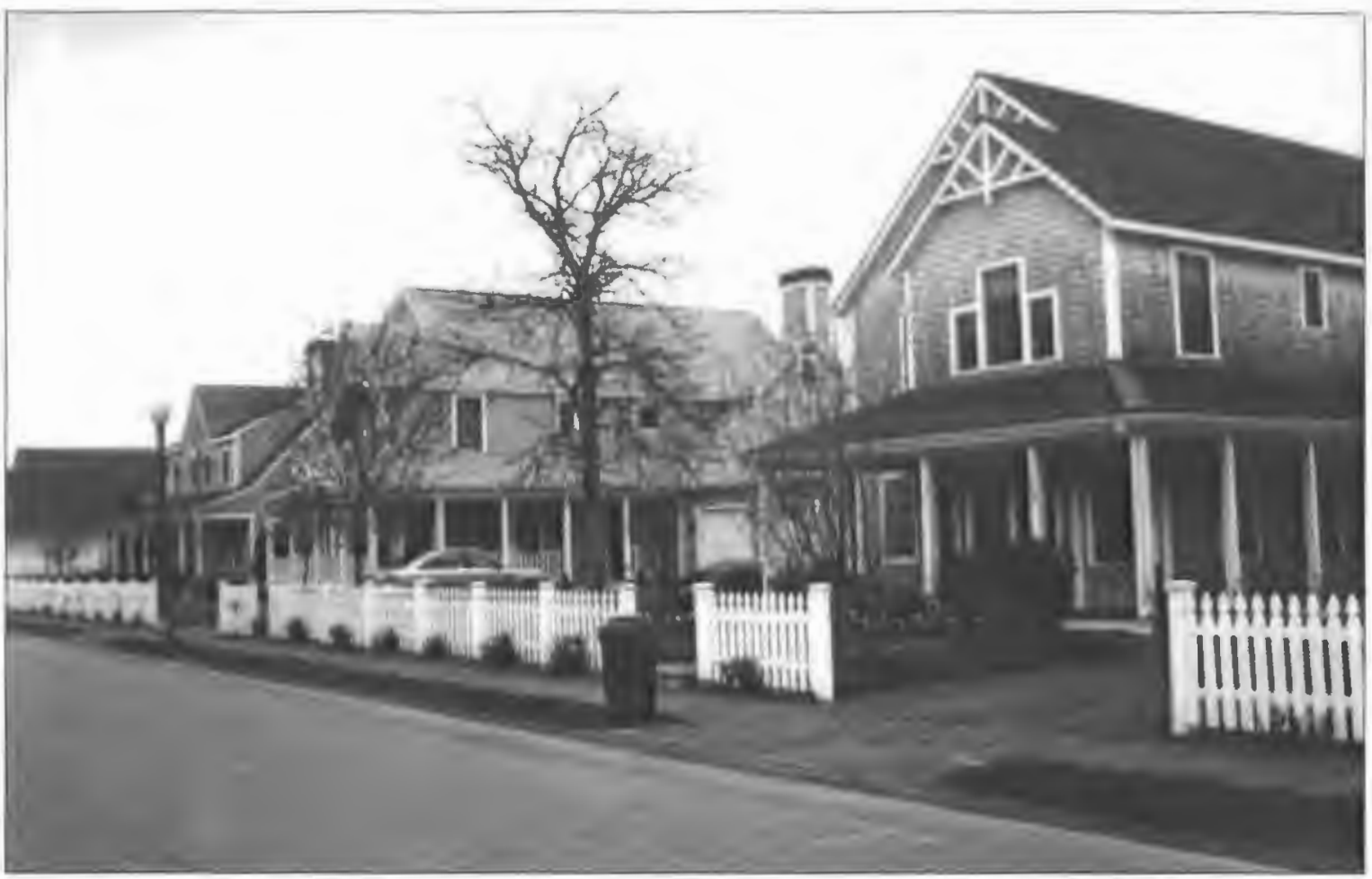

Figure 25. Houses in Wickford Point

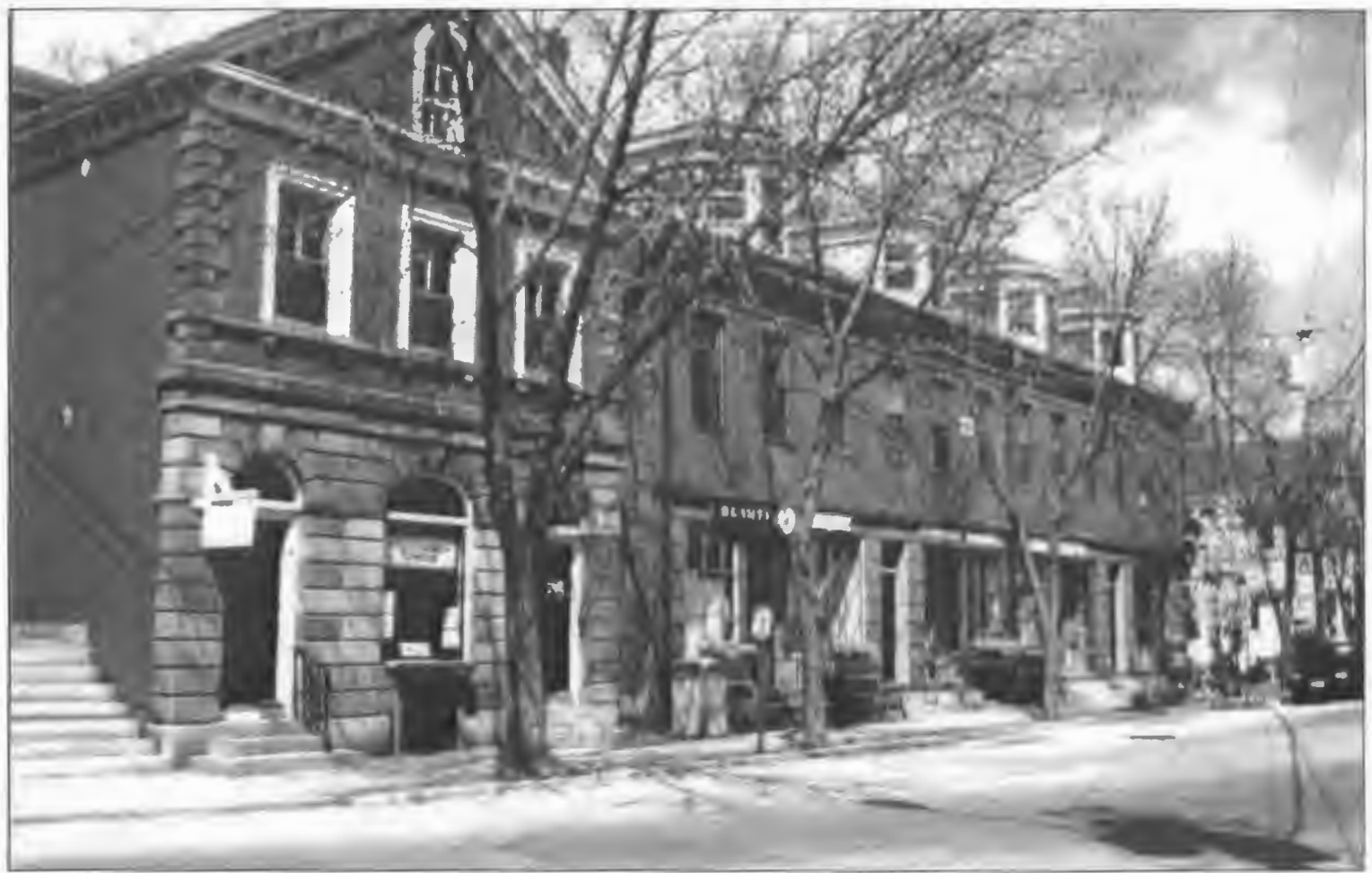

Figure 26. Mixed use in Wickford Village 
advocates the development of high-density villages around public transit nodes. Calthorpe envisions the pedestrian pocket as a place where many of the needs can be served within walking distance of one's home. Calthorpe recognizes, however, that a village cannot meet all of the needs of its residents. When it is necessary to leave the community to work, for example, one can walk to the public transportation station, thus avoiding use of an automobile.

Zoning has been seen as a roadblock to sustainable development patterns called

for by new urbanists. However, Warwick's ordinance allows for special zones that allow for many of the design and site planning principles of New Urbanism. Cluster zoning allows for a higher density of development to preserve open space. The PUD overlay district allows for a mix of uses. A creative combination of these tools enable us to integrate many new urbanist principles into the redevelopment of Rocky Point.

\section{A Redevelopment Plan for Rocky Point}

This plan proposes a mixed-use development for the land in the study area. Under this plan, which utilizes the PUD and cluster zoning tools, residential, commercial, and recreational uses will co-exist. There will also be a rehabilitation of many of the existing structures, and provisions for water transit through restoration of the pier.

The method used for this plan first addresses the preservation of environmentally sensitive and strategically outstanding land for open space. Once the areas for preservation are identified, most of the remainder of the land is divided for residential, commercial and a mix of both uses. It should be noted that not all of the land in the project area is included in this plan. Certain parcels outside of the amusement park area 
are not conducive to redevelopment under this plan and are proposed to be sold. Their disposition is addressed further in the next chapter.

Once the uses for the land have been established, transit, utilities and demolition are addressed. Design, including New Urbanism concepts, will play an important role in this new development. For each component of the plan, design standards will be suggested that will foster an integrated look and feel to the village. The standards will also serve to encourage walking while accommodating automobiles.

Open Space/Public Use

Arendt's (1996) method of subdividing land calls for first identifying the most valuable land to preserve. This land typically has outstanding environmental features such as providing wildlife habitat, buffering coastal features and affording views of natural beauty. According to Arendt, "primary conservation areas" include unbuildable wetlands, floodplains and steep slopes. "Secondary conservation areas" are those parts of "buildable upland that are most sensitive environmentally, most significant historically, most scenic, or which possess unusual attributes that cause them to stand out from the rest of the property as areas that the average observer would miss most if they disappeared under new houselots and streets" (p. 41).

To identify primary and secondary conservation areas, we turn to the environmental analysis of Chapter Three. The composite map of Figure 7 shows the steep slopes, unsuitable soils, wetlands and floodplains. These areas are our primary conservation areas. Coincidentally, these areas provide the best parkland. 
Figure 27 shows the proposed network of open space. The primary conservation areas include the entire coastline in the study area, featuring the two beaches, the ball field, the high ground to the west of the Shore Dinner Hall and Rocky Point. Wetlands in the south and west of the property and the wooded highlands, all unsuitable for development, will also be preserved. This total area is approximately 72 acres. The only improvements proposed for these open spaces are paths through the woods and minor enhancements to the ball field. Secondary conservation areas are a formal village green to the north and an area around the former carousel in the midway area, a total of roughly two acres.

This method of conservation has the added bonus of avoiding many regulatory hurdles. Under this plan, no wetlands will be altered and no buildings will be erected in the 100-year floodplain or in the 200-foot coastal zone. Assent from CRMC would be needed for improvements to the road and walking/biking paths, but since the road is already there, it is not anticipated that the assent would be difficult to secure.

\section{Rocky Point Village}

A mixed-use village is proposed for the area encompassing the roughly 50 acres of developable land in the former amusement park midway, the parking lot to the north and the Rocky Beach area (Figure 28). This area will combine commercial, recreational and residential uses. A planned unit development (PUD), providing areas of mixed residential and commercial uses will be integrated with a cluster housing development to create a cohesive village in the New Urbanist tradition. 


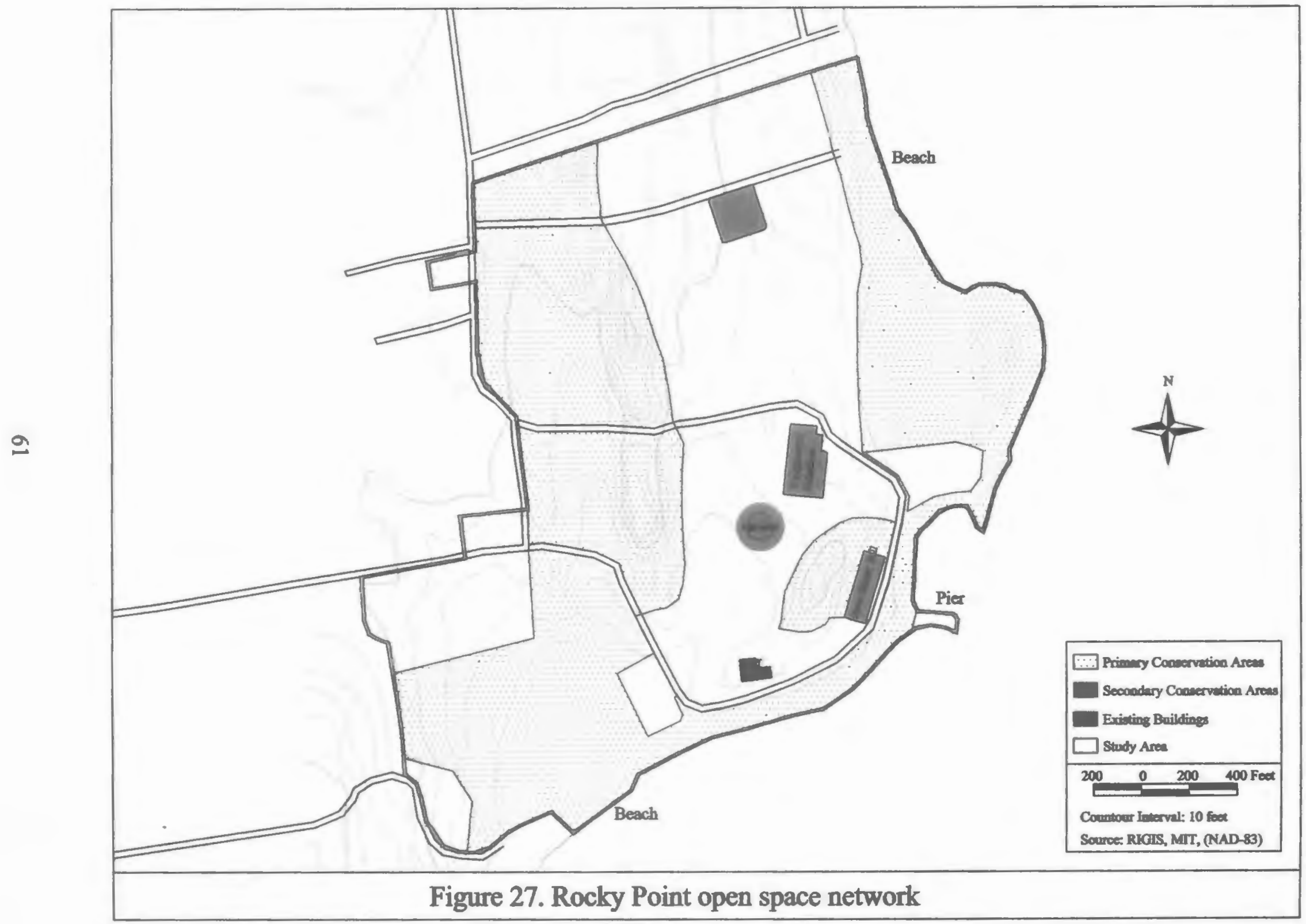




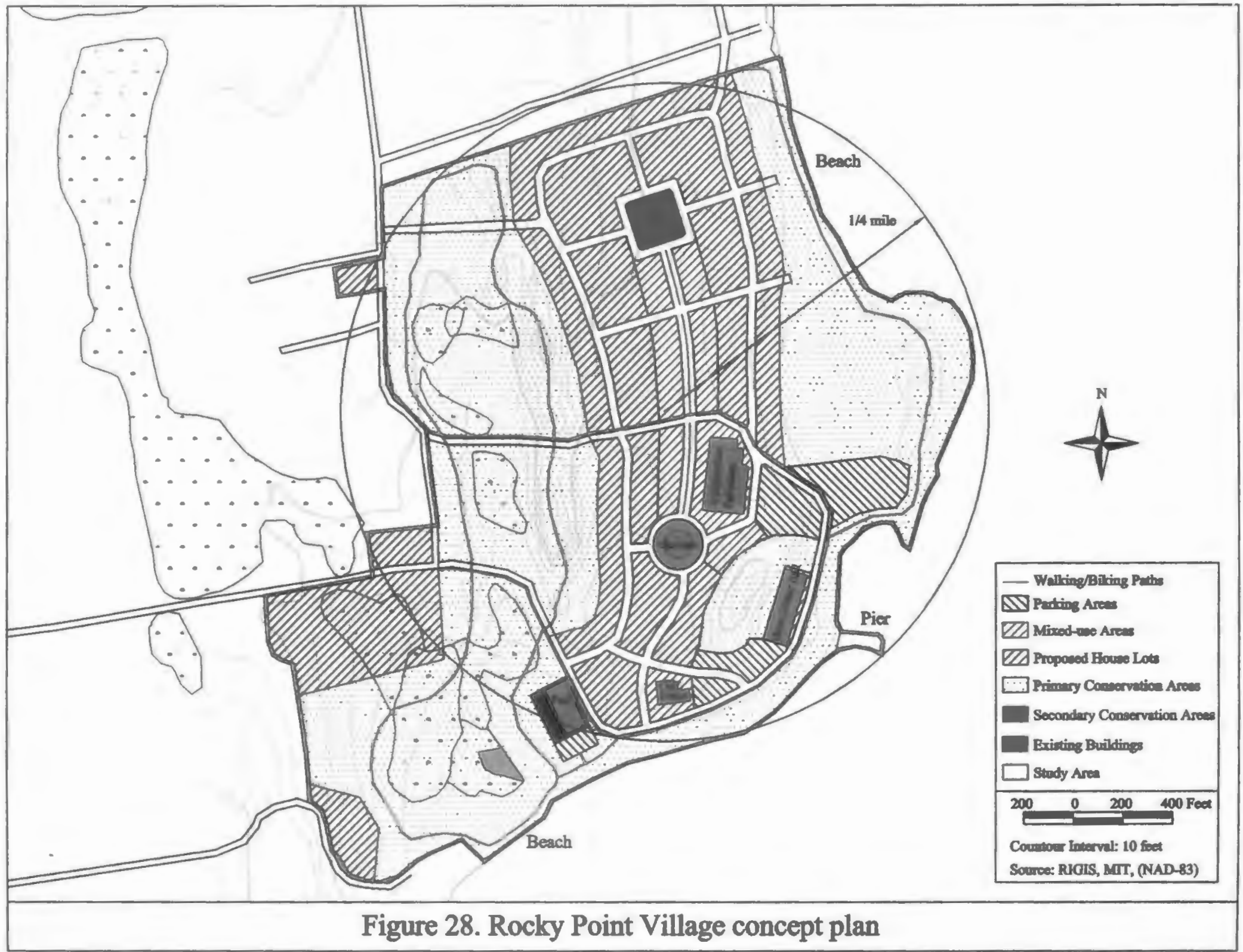


Central to this development will be the rehabilitation of many of the existing structures. These structures, plus newly-constructed buildings, will house a mix of residences and businesses that will serve the residents of the area and visitors to the village.

The study area is appropriately sized to incorporate the New Urbanism principle that the walk to the center of the community should be no longer than $1 / 4$ mile. Figure 28 shows that the radius of village at Rocky Point is $1 / 4$ mile. This plan take advantage of the size of the study area to integrate housing, commercial facilities, recreation and transportation in a compact, walkable community.

\section{Planned Unit Development}

Between newly created mixed-use areas and the uses proposed in the existing structures, there is a total of approximately 14 acres of mixed-use land in the village.

Five existing structures are slated to be rehabilitated to reflect their former uses but also to accommodate new uses. Three, the Cliff House, the Shore Dinner Hall and the Palladium/Windjammer complex, are located at the edge of the midway, facing out towards the access road and the water. The carousel is located in the center of the former midway. The pool is located to the southwest of the midway.

The Cliff House was formerly a restaurant and lounge. The plan calls for the restoration of this use. The building sits high above the shore of Narragansett Bay, and offers unobstructed water views. It also features a patio facing towards the midway. During the summer, the Cliff House would be a great place for al fresco dining, but 
would operate year-round. Parking for the Cliff House can be accommodated in the existing parking lot between it and the Shore Dinner Hall.

The Shore Dinner Hall once served seafood dinners to thousands in its cavernous hall. This type of dining is probably not viable today. However, even after the park closed, the ground-level take-out window, on the east side of the building facing the pier, was popular with visitors. The facilities exist to reopen the take-out window to serve foot, automobile and water traffic. Depending on the size of the take-out operation, other businesses could possibly operate out of the 300-foot frontage of the ground level of the building.

The former hall, on the second floor, with its access from the parking lot on the south side of the building, could be converted into apartment units. It is feasible to build one or two stories on top of the building to construct townhouse units or other types of apartments. The residential part of the building would have a private entrance, separate from the first floor businesses, and parking in the adjacent lot. The apartments would feature unobstructed water views. Setbacks of upper floors would provide balconies for the units. A rendering of the proposed renovation is shown in Figure 29.

In its heyday, the Palladium/Windjammer complex could accommodate up to 3,000 for functions. This plan calls for either a rehabilitation of this complex, or a reconstruction of a function hall in the same place, depending on the condition of the buildings. It is questionable whether Warwick needs a 3,000-seat function hall, or that parking would be available for a use of this size. However, a moderately-sized hall in this location, with views of conservation land and the Bay, would likely be competitive with other similarly-sized buildings. Parking for this facility can be accommodated in the 


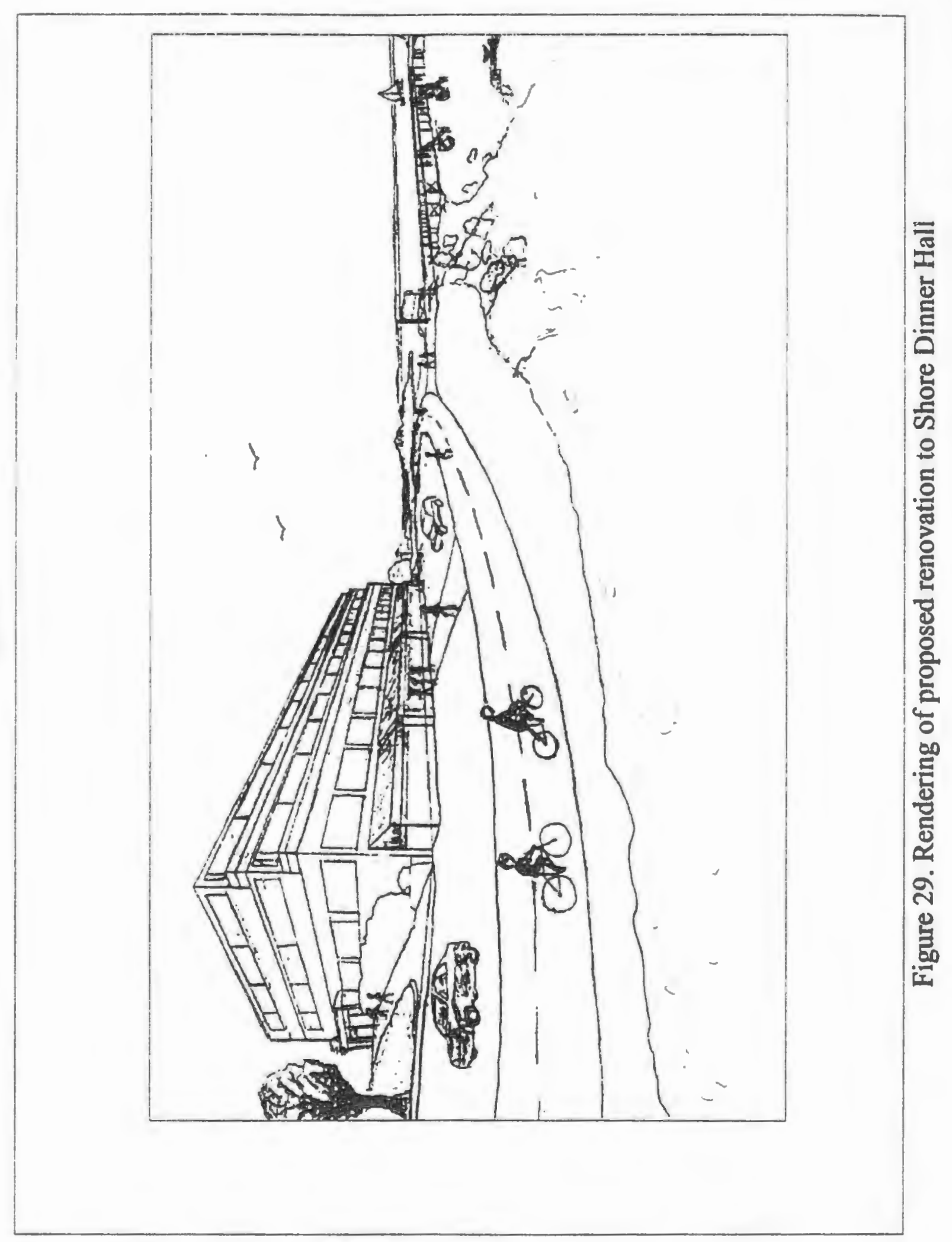


existing adjacent lot and within the midway area.

The carousel building, in the center of the midway, is an appropriate focal point and landmark for the village and as an area for a public space. This building could be restored to house a new carousel, or could perhaps be used as a gazebo for public events. The open space around the carousel will be connected to the green area to the north by a boulevard with a green median. The saltwater pool was once a popular public attraction. This plan proposes the restoration of the pool to be operated either by the city, by a private owner or by a residents association.

The boulevard between the carousel and the green in the northern part of the village will be the main street of the village. The area surrounding it dedicated to a mix of commercial and residential, and possibly municipal uses. It should contain street-level retail uses and be wide enough to accommodate parking on both sides of the street. Additional parking and services could also be provided for in alleys behind the commercial structures. Sidewalks should be wide enough to encourage pedestrian traffic and the buildings should be built with shallow or no setbacks from the sidewalks. Upper floors of the retail buildings would be appropriate for residential units.

\section{Cluster Housing Development}

Areas of exclusively residential uses will surround the commercial development. Creative zoning options should be considered for these areas. Because so much land is proposed to be preserved, cluster housing is appropriate for this development. A New Urbanist-style development of single-family houses is one possibility. 
It is proposed that all of the residential land in the village area be zoned A-15. By using the cluster technique, the minimum lot size becomes 9,000 square feet. The ordinance specifies that $20 \%$ of upland in the housing development be dedicated as open space. Including 4.5 acres of primary and secondary open space already delineated, there are 36 acres available for house lots in the village. Not including the open space, there are 31.5 acres available. The total amount of land needed so that $20 \%$ may be preserved and 31.5 acres may be developed is $31.5 / 0.8=39.4$ acres. It is proposed, therefore, that approximately 3.5 acres of upland outside of the village, perhaps bordering other open space, be dedicated open space for the purposes of the cluster ordinance. This land will augment the open space already preserved in the village.

In keeping with the ordinance, we must deduct $20 \%$ of total lot area $(0.2 * 31.5=$ 6.3 acres) for roads. The remaining 25.2 acres may then be subdivided into 9,000 square foot lots. This acreage can accommodate up to 122 house lots.

In this type of neighborhood, the small size of the lots is mitigated by the open space in the village and in the surrounding area. In the New Urbanist tradition, the houses would have shallow setbacks from the roads. Parking would be to the rear of the houses to emphasize the facades of the houses and to de-emphasize the garages. This development could incorporate a mix of architectural styles. Buildings should be situated to take maximum advantage of views towards the water and the conservation land.

The same principles of a mixed-use village would apply to a condominium development, attached apartment units, single-family houses, or a combination of all of these styles. The city would need to explore issues of density with alternate housing options, however. 
The roads in this plan are laid out is a semi-grid pattern. The grid pattern, unlike the conventional suburban hierarchical road pattern, allows for a choice of routes through a development and a dispersal of traffic (Katz, 1994). The residential streets have sidewalks to encourage walking. The right-of way for the streets should be narrow, perhaps two 9-foot travel lanes to discourage speeding. Planting strips between the road and the sidewalk are encouraged. The plan shows that a walking/biking path from the end of Burnett Road will link the new neighborhood to Highland Beach. The city and developers might wish, however, to extend Burnett Road into the new development.

\section{Water Transit}

Under this plan the pier at Rocky Point will be rehabilitated and will be operated by the city or the state to provide alternate transit options for people who live in the development or nearby. The pier is accessible to and from the access road and the network of open space. It will be used by pleasure boaters who might, as in the past, tie up and visit the Shore Dinner Hall's take-out window. Also as in the past, the pier will accommodate commercial tourist ships. A new use for the pier will be as a commuter ferry service. Ferries proposed to run between Newport, East Greenwich and Providence could stop at Rocky Point with virtually no detour. Parking for commuters would be accommodated in the unpaved lot just south of Rocky Point or in lots adjacent to the Shore Dinner Hall and Windjammer/Palladium complex. 


\section{Utilities}

As described in Chapter Three, Rocky Point is already serviced by water, electricity and gas. It will be relatively easy to extend the existing service to the newly developed areas. The property is not sewered, however. To accommodate the intensive use called for in this plan, sewers would be necessary. The nearest sewer main runs along Warwick Neck Avenue, roughly 2,000 feet to the west of the entrance to the park. It was installed to service the Anglesea housing development on Warwick Neck. According to Councilman Carlo Pisaturo, this line was designed to handle new development at Rocky Point. To transport sewage uphill to this line, a pumping station would be necessary in Rocky Point. Since the new development will necessitate excavations for new sewer, gas and water feeds, underground electric and cable lines should be considered as well.

Stormwater that falls on the acres of paved surface of Rocky Point is carried either overland or through storm drains directly into the Bay, with no treatment. While new development at Rocky Point will likely result in a net increase in pervious surface in the form of lawns and vegetated areas, RIDEM will require that a water quality certificate be issued prior to creating new stormwater discharges to waters of the state. Stormwater will likely have to be treated before being released into the Bay to remove suspended solids. Treatment may be accomplished by the use of a sedimentation basins. Where sedimentation basins are infeasible, centrifugal stormwater treatment structures might be used. 


\section{Demolition}

Numerous foundations and up to 20 acres of asphalt in the development will have to be removed for this development. The Rocky Beach area contains approximately 70 small cottages, most of which are owned by individuals who lease the land from the owners of the Rocky Point parcels (an unknown number of the cottages is owned by the Rocky Point landowners). For redevelopment of this area, the cottages will need to be removed. In some cases, owners may choose to move their own cottages, but it is likely that many owners will abandon their houses, necessitating their demolition by owners of the property. Except for Rocky Beach Avenue, the roads in Rocky Beach are dirt. Little removal of pavement would be necessary in this area. All areas proposed to be developed have previously been developed. Therefore, little clearing of vegetation will be required.

\section{Conclusion}

This chapter describes a scenario for a new beginning for Rocky Point. Under this plan, it will be a cohesive community that not only serves its residents, but its visitors as well. It will have private and public spaces, residential and commercial uses, recreational and transit uses, all within a short walk of each other. Rocky Point should be developed in this manner because it is appropriate for the site's constraints and opportunities and consistent and respectful of its historical uses.

Perhaps more importantly, this type of development is appropriate for infill development in Rhode Island. Compact, mixed-use villages use land more efficiently than do large-lot, single-family subdivisions. More efficient infill development helps to 


\section{Chapter Seven}

\section{Implementation}

\section{Introduction}

This chapter addresses implementation of the redevelopment plan presented in Chapter Six. It estimates the costs involved with the improvements to the land in the study area. It addresses fiscal the impacts to the city with respect to tax revenues from the development and services the city must provide. It discusses sources of funding that could be used for the acquisition of open space. Finally, actions that the city might take to ensure the implementation of this plan are considered.

The presented figures give a rough estimate of the costs associated with implementation of the plan. A detailed plan would be needed (e.g. a physical examination of the conditions of existing buildings and a hazardous materials site assessment) to more precisely estimate the costs of implementation.

The implementation of the plan specifies different dispositions for the many lot in the study area. To simplify matters and to avoid the issue of having to negotiate with the Small Business Association, the several owners and the bankruptcy court over specific parcels, it is assumed that a developer implementing this plan will acquire the entirety of the land in the study area in a fee simple purchase (acquisition costs are addressed below). The developer will then sell off house lots that are not within the proposed village area, sell land to government or non-profit agencies for open space, improve the property within the village area and then sell those improved lots. 


\section{On- and Off-site Improvements}

This estimate is based on improving the property to the point where individual lots in the new village can be sold. It includes all costs associated with demolition, road construction and installation of the required utilities.

Table 1 lists the estimated costs associated with on- and off-site improvements. Demolition costs are for the 20 acres of pavement in the midway and north parking lot, the numerous foundations and structures in the midway and the 70 cottages in Rocky Beach that will likely have to be demolished. From the site survey it is estimated that the total area of buildings in the midway is 50,000 square feet and the 70 cottages are approximately 500 square feet each. Therefore, the total building area to be demolished is roughly 85,000 square feet.

\section{Table 1. Site improvement costs}

\begin{tabular}{|c|c|c|c|c|}
\hline & Unit & Cost/Unit & Quantity & Cost \\
\hline $\begin{array}{l}\text { Demolition } \\
\text { Remove \& Dispose Pavement } \\
\text { Demolish Wood Buildings, Slabs }\end{array}$ & $\begin{array}{l}\text { s.y. } \\
\text { s.f. }\end{array}$ & $\begin{array}{l}\$ 3.50 \\
\$ 1.75\end{array}$ & $\begin{array}{l}96,800 \\
85,000\end{array}$ & $\begin{array}{l}\$ 338,800 \\
\$ 148,750\end{array}$ \\
\hline 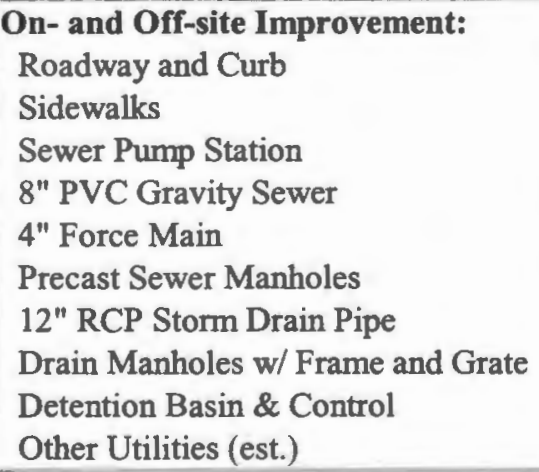 & $\begin{array}{r}\text { l.f. } \\
\text { l.f. } \\
\text { each } \\
\text { l.f. } \\
\text { l.f. } \\
\text { each } \\
\text { l.f. } \\
\text { each } \\
\text { each }\end{array}$ & $\begin{array}{r}\$ 60 \\
\$ 15 \\
\$ 100,000 \\
\$ 30 \\
\$ 10 \\
\$ 200 \\
\$ 25 \\
\$ 250 \\
\$ 20,000\end{array}$ & $\begin{array}{r}9,660 \\
9,660 \\
1 \\
14,570 \\
2,000 \\
20 \\
2,500 \\
12 \\
1\end{array}$ & $\begin{array}{r}\$ 579,600 \\
\$ 144,900 \\
\$ 100,000 \\
\$ 437,100 \\
\$ 20,000 \\
\$ 4,000 \\
\$ 62,500 \\
\$ 3,000 \\
\$ 20,000 \\
\$ 100,000\end{array}$ \\
\hline Subtotal & & & & $\$ 1,958,650$ \\
\hline Soft Costs $(20 \%)$ & & & & $\$ 391,730$ \\
\hline Total & & & & $\$ 2,350,380$ \\
\hline
\end{tabular}

Source: Maguire Group (1996, 1999) 
There are approximately 9,660 feet of new roads proposed for the village. Sewer lines will run throughout the development and connect to the line that runs along Warwick Neck Avenue via a pumping station and a force main to pump sewage up Rocky Point Avenue to this line.

There are existing water, gas, electric and telephone services at Rocky Point and Rocky Beach. To feed these utilities to the new areas of development might cost another $\$ 100,000$. When soft costs for professional services such as surveying, delineating wetlands and permitting are figured in, the cost for the improvement of the land in the proposed village is estimated to be $\$ 2,350,380$.

\section{Revenues}

Once the entire property acquired, it is proposed that land not to be developed for the village be immediately sold. The remaining land will then be subdivided, improved, and sold. There are four categories of property to be sold: house lots outside of the village, land for open space, residential and commercial lots within the village and existing buildings within the village. Estimates of what these pieces of property could fetch are based on appraisals, 1997 tax assessments and the sales of equivalent properties.

\section{House Lots Outside of the Village}

Lots not proposed to be used for open space or within the village include Plat 381, Lot 38 and Plat 379, Lots 426, 9, 158 and 159. Lots 158 and 159 are currently in use as one piece of property with an occupied single-family house. Their combined assessment, from the Warwick Tax Assessor's Office, is \$93,400. Lot 9, with the abandoned house, is 
assessed at $\$ 134,400$. The other lots are presumed to be buildable. Lot 38 is assessed at $\$ 33,340$. Lot 426 is assessed at $\$ 68,700$. The total assessed value of these properties, therefore, is $\$ 329,440$. It is assumed that this is their fair-market value.

\section{Land for Open Space}

From the last chapter, there are 74 acres of open space proposed. Eight of these acres would be developed as part of the cluster housing development and perhaps administered by a neighborhood association. It is recommended that the remaining 66 acres of land be sold to the public sector for conservation land. An appraisal for open space in the study area (Cooke, 1996b) estimated 47 acres of land along the shoreline to be worth between $\$ 28,000$ and $\$ 30,000$ per acre. Using these figures, the 66 acres would be worth between $\$ 1,848,000$ and $\$ 1,980,000$. These figures may be high, however, in consideration of other Rhode Island properties that have been recently purchased for open space. For instance, a 229-acre farm in Tiverton was bought in April of 2000 by eight collaborating organizations for $\$ 1.2$ million (Fassihi, 2000). This equates to $\$ 5,240$ per acre. At this rate, the 66 acres at Rocky Point would be worth $\$ 345,840$. Other properties

have been more costly, however. On Aquidneck Island, a 50-acre farm was purchased for $\$ 615,000(\$ 12,300$ per acre) (Martinez, 2000). Also, 36 acres of forest in Portsmouth were purchased for \$1.5 million (\$41,666 per acre) (Martinez, 2000).

Based on these figures it is difficult to precisely estimate the value of the Rocky Point open space. Some of it is along the shore, some is wetland. The former landfill is also in this area. Virtually all of the land is undevelopable. For purposes of this project 
we will assume a price of $\$ 20,000$ per acre for the open space land, for a total of $\$ 1,320,000$.

Property Within the Village

The value of property within the village is estimated assuming the property is improved and ready to be built upon, or already developed. In the plan of Chapter Six it was calculated that there could be roughly 122 house lots at 9,000 square feet each in the village. There are roughly 14 acres of mixed-use land in the plan. When we subtract $20 \%$ for roads, the plan can accommodate the equivalent of 54 more mixed-use lots at 9,000 square feet each (some lots may be larger, but the ratio of size to price is assumed to be constant). The total number of lots would then be 176 .

To estimate the value of the lots, we can compare values of similar property. Waterfront and water-view lots in the Anglesea development in Warwick Neck are assessed at between $\$ 100,000$ and $\$ 240,000$ for one to $1 \frac{1}{2}$ acre lots. Assessments for 15,000 to 20,000 square-foot lots in Highland Beach and Lighthouse Estates, a development north of Highland Beach, are between $\$ 40,000$ and $\$ 80,000$. Seaside Estates, a new development on the former Crescent amusement park land in East Providence, is selling $1 / 4$ to 1 acre lots at between $\$ 54,900$ and $\$ 209,900$. Some of these lots have views of Bullock's Cove. However, most homes at Rocky Point will have water views, and those views are much more attractive than the view of Bullock's Cove. Considering the other amenities, such as commercial space and parkland, and the proximity to valuable land in Warwick Neck, it is not unreasonable to estimate that on 
average, commercial and residential lots could be worth at least $\$ 60,000$ each. The 176 lots would then be worth $\$ 10,560,000$.

\section{Existing Buildings Within the Village}

The existing buildings within the PUD are to be sold to parties that will rehabilitate them. Their value is based on their tax assessment: for the Cliff House, $\$ 230,150$, for the Shore Dinner Hall, $\$ 680,990$, for the Palladium/Windjammer, $\$ 555,480$. (Rock Cottage is assessed at $\$ 235,500$. Even though this building is planned to be demolished due to its visibly deteriorated condition, it could also be considered for rehabilitation.) The three buildings total $\$ 1,466,620$ in assessed value. These properties will be made more valuable when the property is rezoned and sewers and new roads are added. However, their current condition could well have deteriorated after being vacant for several years, thus lowering their values. It is assumed, therefore, that this figure is their fair-market value.

\section{Total Revenues}

Under this scenario, the total revenues from the development and sale of the property would be $\$ 329,440+\$ 1,320,000+\$ 10,560,000+\$ 1,466,620=\$ 13,676,060$.

\section{Site Acquisition}

The fair-market value for site acquisition is addressed last because this price is dependent on the costs of improving the land and the revenues expected from selling individual parcels. 
As discussed, the Rocky Point property has been on the market for $\$ 10$ million since May of 1999. As of this writing, the Small Business Administration (SBA) controls the assets of Fairway Capital Corp. and Moneta Capital Corp., the majority owners of the land. Under these circumstances, the SBA will likely have influence over the sale price. For purposes of this study, the sale price is estimated to be the fair market value of the property assuming that it will be zoned to accommodate the development described in Chapter Six and also considering the substantial costs necessary to improve the property.

The appraisal done for the city in 1996 (Cooke, 1996a) determined a value for a portion of Lot 1 in Plat 380 and for Lots 38, 39, 40 and 41 in Plat 381 (Rocky Beach and the existing house lots are not included). It calculated that there could be approximately 61 lots divided between 15 acres of A-15 zoned land and 19 acres of A-40 zoned land. It found the market value of the lots to be between $\$ 15,000$ and $\$ 17,000$ each for a total of between $\$ 951,000$ and $\$ 1,037,000$. The appraisal noted that the estimate does not take into account the cost of sewers or the removal of hazardous waste, if necessary.

To assess the value of the unimproved land in the village area, we again assume that there are 176 lots at 9,000 square feet each. At a price of $\$ 15,000$ to $\$ 17,000$ per lot, the value of the land in the village area is between $\$ 2,640,000$ and $\$ 2,992,000$.

The market value of all of the land in the study area is therefore the value of the land and buildings in the village area plus the values of the open space land and the house lots to be sold. It is estimated to be $\$ 2,992,000+\$ 1,466,620+\$ 1,320,000+\$ 329,440=$ $\$ 5,778,620$. Using the lower figure for the land in the village, the total is $\$ 5,426,620$.

In comparison, the total assessed value of all the land and buildings in the study area (not including the Rocky Beach Cottages) is $\$ 6,437,720$. At least $\$ 500,000$ of this 
assessment is for buildings that are proposed to be demolished, such as Rock Cottage, all the concession stands, ticket booths and the House of Horrors. A value of between $\$ 5.4$ and $\$ 5.9$ million therefore seems reasonable for the land in the study area (a value of $\$ 10$ million does not seem reasonable).

\section{Return on Investment}

If we assume the property can be acquired for $\$ 5.4$ million, improved for $\$ 2.4$ million and then sold for a total of $\$ 13$ million, the return on investment would be $63 \%$. For this development to be profitable, the open space and other parcels would have to be sold soon after the property is acquired and the implementation of the improvements would have to begin immediately. A developer would be wise to at least have a promise for the purchase of open space and to have the new zoning enacted before taking possession of the property.

\section{Fiscal Impact}

The fiscal impact to the City of Warwick of the proposed development includes the tax revenue from the property minus the cost of services the city must provide to the development. Table 2 shows the tax revenue calculations.

We will assume that there will be 122 houses averaging 2,000 square feet in size. The assessed values of land and buildings are proposed to average $\$ 225,000$ each, in between the pricey houses to the south and the more moderately-priced houses to the north. It is also proposed that mixed commercial and residential uses occupy 
approximately 50,000 square feet in new and existing buildings on the equivalent of 54 9,000 square foot lots.

Table 2. Tax revenues

\begin{tabular}{|l|lrrrrr|}
\hline & \multicolumn{1}{|c}{ Amount } & Value per & $\begin{array}{c}\text { Assessed } \\
\text { Value }\end{array}$ & $\begin{array}{r}\text { Tax Rate } \\
\text { per } \$ 1,000\end{array}$ & $\begin{array}{c}\text { Tax } \\
\text { Revenue }\end{array}$ & $\begin{array}{r}\text { Revenue } \\
\text { to Schools }\end{array}$ \\
\hline Housing Units & 122 Houses & $\$ 225,000$ & $\$ 27,450,000$ & $\$ 23.87$ & $\$ 655,232$ & $\$ 380,034$ \\
Commercial Buildings & 50,000 s.f. & $\$ 50$ & $\$ 2,500,000$ & $\$ 31.83$ & $\$ 79,575$ & $\$ 46,154$ \\
Commercial Land & 54 lots @9,000 s.f. & $\$ 60,000$ & $\$ 3,240,000$ & $\$ 31.83$ & $\$ 103,129$ & $\$ 59,815$ \\
& & & & & & \\
\hline Total & & & & & & \\
\hline
\end{tabular}

Source: Warwick Tax Assessor's Office

For the residential property, the tax revenue would be $\$ 655,232$. According to the Warwick Tax Assessor's office, roughly 58\% of tax revenues are dedicated for schools and the remainder is for other city services. Therefore, the school revenue from residential development would be $\$ 380,034$. The tax revenue from commercial property would be $\$ 82,704$, with $\$ 105,969$ going to schools. The total tax revenue is therefore $\$ 837,936$, with $\$ 486,003$ for schools. This figure would be augmented somewhat by automobile tax and tangible property tax.

According to the Warwick fiscal year 1999-2000 budget, property taxes contributed $\$ 78,337,624$ to schools in fiscal year 2000 , for 12,200 students. The average per student is therefore $\$ 6,421$ per student (additional education funds came primarily from the state). The residential tax base does not pay for all of the school services. Commercial and industrial uses supplement the funding. Therefore, under the current tax structure, on average, new residential property not balanced by new commercial or industrial development will be a net drain on city coffers. However, residential development with houses that are assessed at values substantially higher than the average 
assessment contribute more in tax money than the educational costs for the children from those houses. Our development is an example of this.

According to the U.S. Census (1990), there was a citywide average of 0.34 students per household (11,379 students / 33,352 households). (In the census tract to the south of Rocky Point, the ratio was 0.31 . In the tract to the north it was 0.39.) Using the citywide ratio, there would be 42 students from the 122 houses in this development. Apartments might contribute another ten students. The total annual education costs to the city for these students would be $\$ 333,892$.

When compared to the revenues for education of $\$ 486,003$, there would be a net gain in revenues to the city from taxes used for education. For other city services, it is assumed that the value of services will be roughly equal to the tax revenue for services although the businesses might need more services for trash collection, for example. Overall, however, it is not expected that this development will consume more in services than it pays in tax money.

\section{Funding Sources}

The acquisition of the open space can be accomplished by funding from the state, the City, non-profit organizations or a combination of both. A $\$ 50$ million dollar state bond referendum will be on the ballot in November (Sabar, 2000). This money would be used by the Rhode Island Department of Environmental Management to acquire open space statewide. Warwick is also considering a bond issue for city acquisition of open space (Malinowski, 2000). Another avenue to explore would be the nascent land trust in Warwick (Providence Journal, 2000). 


\section{Warwick's Role in Implementation}

The city can play an important role in ensuring that Rocky Point is developed in a manner that is appropriate for the site. The best way to accomplish this is to preemptively rezone the property so that it might be able to accommodate the PUD described in Chapter Six. To acquire open space the city can work to secure the funding and negotiate with developers over donations of open space in return for higher development density. Finally, it can expedite the process of permitting a development plan so that work may begin soon and a substantial investment in this property will have a reasonable return. 


\section{References}

Arendt, Randall. 1996. Conservation Design for Subdivisions. Washington, DC: Island Press.

Breed, Donald D. 1995. "Creating a traditional seaside village." Providence Journal, November 19, 1995. p. G-1. Providence: Providence Journal Co.

Broberg, Lisa. 1996. "Banknupt Rocky Point future on a merry-go-round." Providence Business News. March 25, 1996.

Calthorpe, Peter. 1993. The Next American Metropolis: Ecology, Community and the American Dream. New York: Princeton Architectural Press.

City of Warwick, RI. 1991. Comprehensive Plan.

City of Warwick, RI. 1995. Zoning Ordinance.

City of Warwick, RI. 1996. Preliminary Environmental Assessment for Rocky Point.

City of Warwick, RI. 1999. Fiscal Year 1999/2000 Budget.

City of Warwick, RI. 2000. Development Review Regulations Governing Subdivisions, Land Development Projects and Development Plan Review.

Cooke, Henry W. Co. 1996a. Real Estate Appraisal, Rocky Point. April 25, 1996

Cooke, Henry W. Co. 1996b. Real Estate Appraisal, Rocky Point, Open Space. August 10,1996

D'Amato, Donald A. 1992. Warwick's 350-Year Heritage, A Pictoral History. Virginia Beach: Donning Company.

DePaul, Tony. 1996. "Rocky Point shutdown fosters anxieties.” Providence Journal, January 16, 1996. p. C-1. Providence: Providence Journal Co.

DePaul, Tony. 1999. "Rocky Point is Up for Sale." Providence Journal, May 23, 1999. p. E-1. Providence: Providence Journal Co.

Duany, Andres and Elizabeth Plater-Zyberk. 1991. Towns and Town-Making Principles. New York: Rizzoli International Publications.

Fassihi, Farnaz. 2000. "Tiverto Land Trust buys 229-acre farm for $\$ 1.2$ million." Providence Journal, April 2, 1996. Providence: Providence Journal Co. 
Howell, John. 1997. "Rocky Point plan offers open space.” Warwick Beacon, May 29, 1997. Warwick: Beacon Communications.

Jarvis, Frederick D. 1993. Site Planning and Community Design for Great Neighborhoods. Washington, DC: Home Builders Press.

Katz, Peter. 1994. The New Urbanism. New York: McGraw-Hill, Inc.

Liberman, Ellen. 1996. "Rocky Point goes on the block." Providence Journal, April 16, 1996. p. B-1. Providence: Providence Journal Co.

Maguire Group, Inc. 1996. Route I Special Management District Development Feasibility Analysis.

Maguire Group, Inc. 1999. Roadway Alternatives, Warehouse Triangle Area, Quonset Davisville Port and Commerce Park.

Martinez, Soljane. 2000. "DEM touts plan to save open space." Providence Journal, April 2, 1996. Providence: Providence Journal Co.

McHarg, Ian L. 1971. Design With Nature. Garden City: Doubleday.

Pisaturo, Carlo. 2000. Interview with the author, 3/14/00.

Polichetti, Barbara. 1996. "Chafee wary of Rocky Pt. bailout.” Providence Journal, March 27, 1996. p. B-1. Providence: Providence Journal Co.

Providence Journal. 2000. "Warwick Land Trust Proposed." Providence Journal, January 11, 2000. Providence: Providence Journal Co.

Rhode Island Coastal Resources Management Council. 1996. Coastal Resources Management Program.

Sabar, Ariel. 2000. "Officials gather to support open-space bond." Providence Journal, January 19, 2000. p. B-8. Providence: Providence Journal Co.

State of Rhode Island, Department of Environmental Management. 1997. Water Quality Regulations.

State of Rhode Island, Department of Environmental Management. 1998a. Rules and Regulations for Governing the Administration and Enforcement of the Fresh Water Wetlands Act.

State of Rhode Island, Department of Environmental Management. 1998b. Rules and Regulations Establishing Minimum Standards Relating to Location, Design, Construction and Maintenance of Individual Sewage Disposal Systems. 
State of Rhode Island, Department of Environmental Management. 1998c. Regulations for the Rhode Island Pollutant Discharge Elimination System.

Wyatt, Donald W. 1995a. "Rocky Point keeps going despite woes." Warwick Beacon, January 12, 1995. Warwick: Beacon Communications.

Wyatt, Donald W. 1995b. "Park owners drove rocky finance road." Warwick Beacon, September 12, 1995. Warwick: Beacon Communications.

Wyatt, Donald W. 1995c. "Homes could replace rides at Rocky Point." Warwick Beacon, October 26, 1995. Warwick: Beacon Communications.

Wyatt, Donald W. 1996a. "Closing saddens many, but hardly a surprise." Warwick Beacon, January 16, 1996. Warwick: Beacon Communications.

Wyatt, Donald W. 1996b. "Retirement Community seen as Rocky Point option." Warwick Beacon, January 23, 1996. Warwick: Beacon Communications.

Wyatt, Donald W. 1996c. "Rocky Point poker game." Warwick Beacon, March 12, 1996. Warwick: Beacon Communications.

Wyatt, Donald W. 1996d. "There's a new life for Rocky Point." Warwick Beacon, April 18, 1996. Warwick: Beacon Communications.

Wyatt, Donald W. 1999. Rocky Point, A Rhode Island Treasure. Warwick: Beacon Communications. 